\title{
Three-way interaction among plants, bacteria, and coleopteran insects
}

\author{
Beata Wielkopolan ${ }^{1} \cdot$ Aleksandra Obrępalska-Stęplowska²
}

Received: 25 November 2015/ Accepted: 30 April 2016/Published online: 11 May 2016

(c) The Author(s) 2016. This article is published with open access at Springerlink.com

\begin{abstract}
Main conclusion Coleoptera, the largest and the most diverse Insecta order, is characterized by multiple adaptations to plant feeding. Insect-associated microorganisms can be important mediators and modulators of interactions between insects and plants.
\end{abstract}

Interactions between plants and insects are highly complex and involve multiple factors. There are various defense mechanisms initiated by plants upon attack by herbivorous insects, including the development of morphological structures and the synthesis of toxic secondary metabolites and volatiles. In turn, herbivores have adapted to feeding on plants and further sophisticated adaptations to overcome plant responses may continue to evolve. Herbivorous insects may detoxify toxic phytocompounds, sequester poisonous plant factors, and alter their own overall gene expression pattern. Moreover, insects are associated with microbes, which not only considerably affect insects, but can also modify plant defense responses to the benefit of their host. Plants are also frequently associated with endophytes, which may act as bioinsecticides. Therefore, it is very important to consider the factors influencing the

Aleksandra Obrępalska-Stęplowska

olaob@o2.pl

1 Department of Agrophages' Forecasting Methods and Agricultural Economic, Institute of Plant Protection, National Research Institute, Poznan, Poland

2 Interdepartmental Laboratory of Molecular Biology, Institute of Plant Protection, National Research Institute, Poznan, Poland interaction between plants and insects. Herbivorous insects cause considerable damage to global crop production. Coleoptera is the largest and the most diverse order in the class Insecta. In this review, various aspects of the interactions among insects, microbes, and plants are described with a focus on coleopteran species, their bacterial symbionts, and their plant hosts to demonstrate that many factors contribute to the success of coleopteran herbivory.

Keywords Plant-insect interactions · Plant-insectmicrobe interactions $\cdot$ Coleoptera $\cdot$ Symbiotic bacteria . Plant response $\cdot$ Protease inhibitors

$\begin{array}{ll}\text { Abbreviations } \\ \text { HAOEs } & \text { Herbivore-associated organisms and elicitors } \\ \text { PR } & \text { Pathogenesis-related proteins } \\ \text { PI } & \text { Protease inhibitor } \\ \alpha \text {-AI } & \text { Alpha-amylase inhibitor } \\ \text { JA } & \text { Jasmonic acid } \\ \text { SA } & \text { Salicylic acid } \\ \text { ET } & \text { Ethylene } \\ \text { ABA } & \text { Abscisic acid } \\ \text { GA } & \text { Gibberellic acid } \\ \text { IAA } & \text { Indole-3-acetic acid } \\ \text { ISR } & \text { Induced systemic resistance } \\ \text { SAR } & \text { Systemic acquired resistance } \\ \text { E-64 } & \text { Trans-epoxysuccinyl-L-leucylamido(4- } \\ & \text { guanidino)butane } \\ \text { AEBSF } & \text { 4-(2-Aminoethyl)benzenesulfonyl fluoride } \\ & \text { hydrochloride) } \\ \text { PCWDE } & \text { Plant cell wall-degrading enzymes } \\ \text { Bt } & \text { Bacillus thuringiensis } \\ \text { PPO } & \text { Polyphenol oxidase } \\ \text { CK } & \text { Cytokinin } \\ \text { PGPR } & \text { Plant growth-promoting rhizobacteria } \\ \end{array}$




\section{Introduction}

It is considered that insects represent $60 \%$ of all species on the earth. Herbivorous insects that constitute half of insects (Schoonhoven et al. 1998) are one of the major factors limiting plant growth and fitness. A two-third of all known herbivorous insects species are leaf-eating beetles (Coleoptera) or caterpillars (Lepidoptera) (Schoonhoven et al. 1998; Howe and Jander 2008). Many beetles have beneficial effect on the environment (nutrient recyclers, pollinators), but significant part of them are pests of economically important crops and storage products. Importantly, coleopteran insects cause considerable economic losses to the important staple food crops worldwide: potato, corn, rice, and cereals. For considerable economic losses are responsible among others Leptinotarsa decemlineata (Colorado potato beetle, Chrysomelidae), Oulema melanopus (cereal leaf beetle, Chrysomelidae), Diabrotica virgifera virgifera (western corn rootworm, Chrysomelidae), Tribolium castaneum (red flour beetle, Tenebrionidae), Dicladispa armigera (rice hispa, Chrysomelidae), Sitophilus oryzae (the rice weevil, Curculionidae), and many others.

Plants are exposed to many abiotic and biotic stresses under natural environmental conditions, and it is important that they coordinate the appropriate responses to limit the damage (Voelckel and Baldwin 2004; Stam et al. 2014). Plants are sessile, therefore, effective defense strategies are needed to prevent them from being eaten by herbivorous insects. Plants have a number of defense mechanisms that directly or indirectly affect herbivorous insects. For example, plants are able to enhance their cell walls through lignification (Garcia-Muniz et al. 1998), and synthesize toxic compounds and volatiles (Kessler and Baldwin 2001). Volatiles may also induce defense responses in neighboring plants. A lot of compounds produced by plants are considered as natural insecticides. For instance, plant protease inhibitors (PIs) which belong to the sixth group of pathogenesis-related proteins (PR-6) are considered natural insecticides (Van Loon 1999).

As evidenced by the huge losses in crop yields every year (Jood et al. 1993; Pike and Gould 2002; Tratwal et al. 2014), it is clear that herbivorous insects are able to overcome plant host defenses (Ogendo et al. 2006; Krattiger 1997). Beetles are naturally equipped with anatomical structures to enable them to feed on plants and also have various biochemical and molecular adaptations to overcome plant defense strategies. For example, in response to plant PIs, insects may produce new protease isoforms that are resistant to plant PIs or produce proteases at a higher rate (Shulke and Murdock 1983; Wielkopolan et al. 2015).

In the ongoing interaction between plants and insects, there are 'hidden' biotic factors, such as microorganisms associated, both, with plants and insects. These 'hidden' factors can significantly influence the plant-insect interaction. Microbes associated with insects may have positive effects on them by aiding in multiple processes, including digestion or protection against pathogens (Dillon and Dillon 2004). In addition, microbes can also modulate plant defense reactions to the benefit of their insects host (Kaiser et al. 2010; Barr et al. 2010). However, microbes associated with plants may also affect the interaction between plants and insects. There is considerable evidence demonstrating that endophytes associated with plants can act as natural insecticides or fungicides (Sturz et al. 1999).

In this review, we focus on plant responses to coleopteran insects as well as the adaptation of those insects to plant feeding and their reactions to plant defense responses. Especially, we would like to emphasis the role of microorganisms associated with herbivorous insects, such as Coleoptera, as the important mediators and modulators of interaction between coleopteran insects and their host plants. We focused on this most numerous insect order not only because of its huge economic importance for agriculture, but also because of its greatest diversity among insect taxa both of which probably are responsible for evolutionary success of Coleoptera. This diversity manifests first of all in the adaptation of Coleoptera to feeding on the wide range of plants (mono- and dicotyledonous), in a variety of niches, which has been continuously expanded starting from pre-Cretaceous period, and in the competition with varying sets of natural enemies. Hence, many articles have been published describing Coleoptera-plant and also Coleoptera-microbe-plant interactions. In this study, we have undertaken to summarize these data indicating also important directions for further studies in this area.

\section{Economic impact of coleopteran species}

Pests belonging to the Coleoptera (the beetles) order are of big interest because of the considerable damages caused by them in the field. The economic impact of widely distributed and harmful chewing insects is described in this part of review.

The order Coleoptera is characterized by the strong screlotized front wings, which protect membranous hindwings (Crowson 1981; Hunt et al. 2007). It is estimated that first beetles appeared around 285 million years ago (Crowson 1981; Grimaldi and Engel 2005). Beetles are characterized by extreme morphological, ecological, and behavioral diversity. Their diversification results most probably from metabolic changes (adaptations to specialized niches and feeding habits) or mutations.

The order Coleoptera includes beneficial insects that may control populations of pests. For example, ladybirds 
(a)

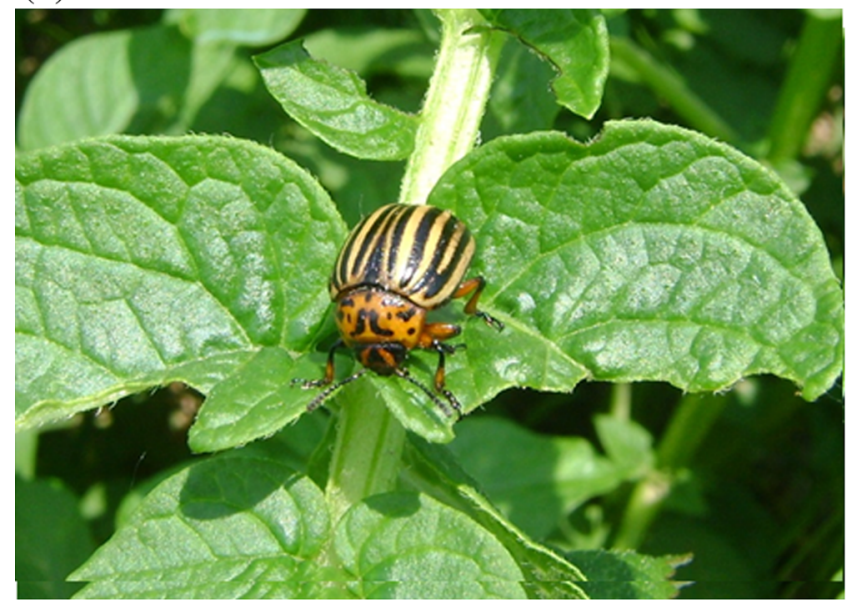

(c)

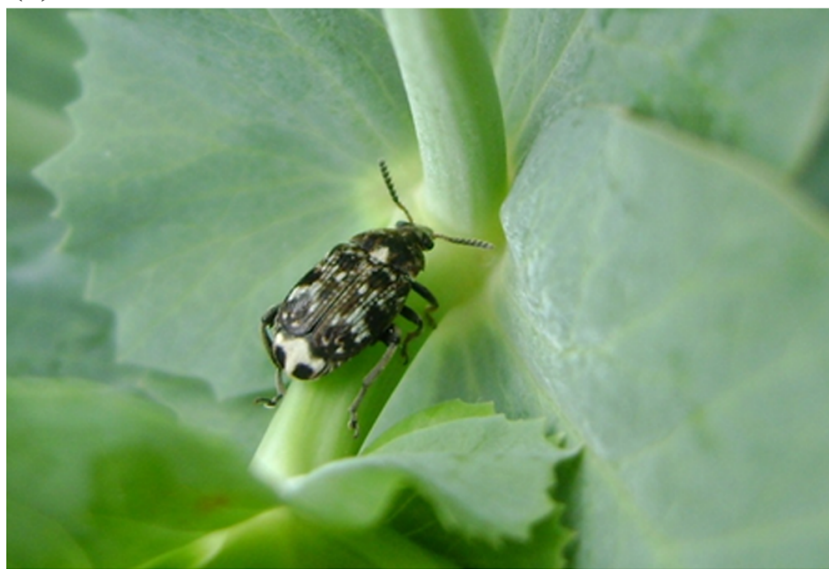

Fig. 1 The examples of coleopteran pests of economically important crops belonging to various taxa. a Leptinotarsa decemlineata on potato (Solanaceae, staple food crop), b Oulema melanopus on wheat (Poaceae, monocotyledonous plant, staple food crop), c Bruchus

(Coccinellidae) may feed on aphids colonies (Minoretti and Weisser 2000). Ground beetles (Carabidae) are predators of many insects, and may reduce cereal and sugar beet aphids population (Kromp 1999). On the other hand, dung beetle (Scarabidae) improves nutrient recycling and soil structure (Brown et al. 2010). However, many beetles cause huge losses in agricultural production. Among them are leaffeeding beetles and pests of storage products. It is estimated that worldwide group of storage products pests includes more than 600 species of beetles (Cao et al. 2002; Rajendran 2002). Their infestations may reduce the quality of stored grain, and change the flavor, odor, and color of plant-derived products (Strang and Kigawa 2006). Infestation may prevent grain import what can cause further economic losses (Cao et al. 2002).

Crop losses due to pests differ in each country, as they depend on various environmental factors, such as meteorological conditions, prevailing flora, and the types of (b)

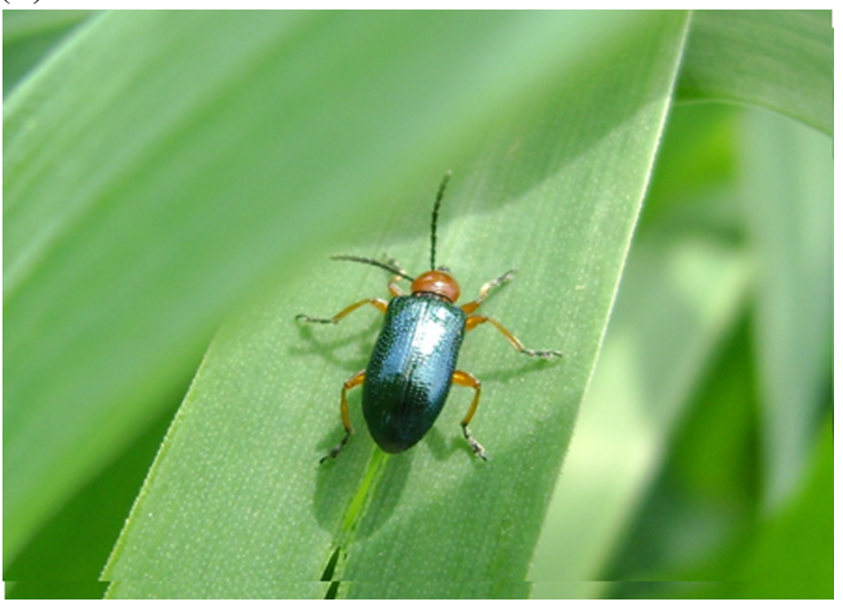

(d)

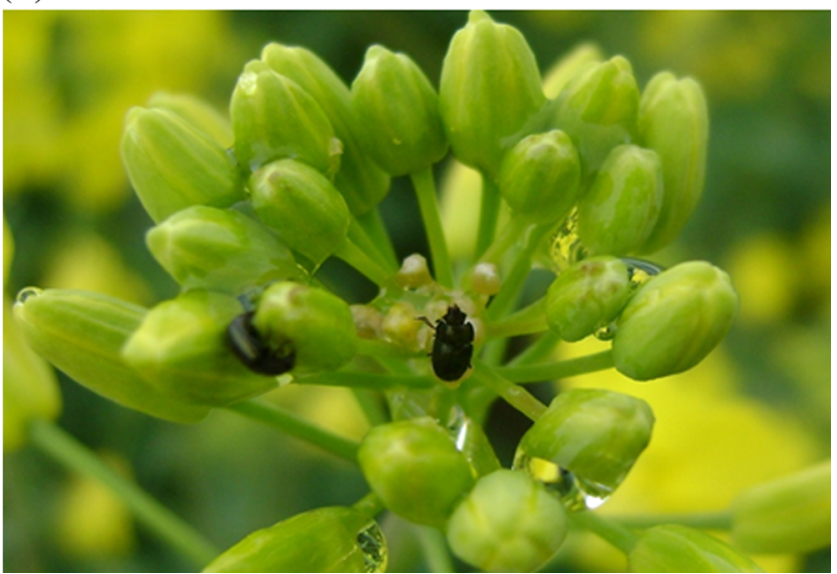

pisorum on pea (Fabaceae, staple food crop), and $\mathbf{d}$ Meligethes aeneus on oilseed rape (Brassicaceae, staple food crop, and plant used for biofuel production)

cultivated crops, as well as the widespread resistance to insecticides. Numerous crop pests, such as the D. virgifera virgifera (maize), L. decemlineata (potatoes and tomatoes) (Fig. 1a), O. melanopus (cereals) (Fig. 1b), Bruchus pisorum (pea weevil, Chrysomelidae (pea)) (Fig. 1c), Meligethes aeneus (pollen beetle, Nitidulidae) (Fig. 1d), Tribolium castaneum or Trogoderma granarium (khapra beetle, Dermestidae) (storage products), blister beetles (Meloidae) (Ghoneim 2013), and Callosobruchus maculatus (cowpea weevil, Chrysomelidae, stored legumes) are globally distributed. Therefore, there are widespread efforts to strictly control them. However, there are pests that are particularly harmful in specific geographic regions, such as Ips typographus (spruce bark beetle, Curculionidae), that is serious pest especially for spruce in Norway and in Eastern Asia, but also in Japan (Christiansen 2008) or Hypothenemus hampei (coffee berry borer, Curculionidae), which is reported in the countries with coffee 
plantations. There are many pests in the Chrysomelidae family alone that are able to damage leaves, roots, seeds, or flowers of susceptible plants. For example, the $D$. virgifera virgifera causes considerable damage to corn fields, especially in the northern USA and Europe. The $D$. virgifera virgifera beetles and larvae are harmful, with the larvae destroying roots and the adult beetles damaging leaves (Levine and Oloumin-Sadeghi 1996). However, larvae are considered to represent the most damaging stage, because their feeding may lead to the decreased ability of roots to transport water and nutrients, resulting in reduced plant growth and grain production (Wright et al. 1999). The larvae and adults of the $L$. decemlineata are responsible for reducing potato crop yields and quality and the resulting negative economic effects. These losses are largely due to the impressive feeding rates of $L$. decemlineata and their high fecundity. In Poland, which is one of the biggest potato-growing countries, an average of $7.1 \%$ of potato plants exhibited $L$. decemlineata feeding symptoms in 2014. However, the damage caused by this pest varied depending on the region with some areas, reporting that $80 \%$ of potato plants were damaged by $L$. decemlineata feeding (Tratwal et al. 2014). An inability to control this pest can lead to the complete destruction of potato fields. Thus, it is very important to control this pest, especially if it has developed resistance to all major classes of insecticides (Alyokhin et al. 2008).

O. melanopus is one of the most important cereal pests. The larvae and adult beetles are both capable of significantly damaging cereal leaf tissue, but the larvae cause greater damage. The larvae feed primarily on the first and second leaves (Groll and Wetzel 1984), and cause reduced crop yield and quality. The annual yield losses caused by the $O$. melanopus are considerable with the level of damage depending on location. For example, grain yield losses ranged from $25 \%$ in the US state of Washington (irrigated spring wheat) (Pike and Gould 2002) to $95 \%$ in The Netherlands (Daamen and Stol 1993), and $70 \%$ in central Europe (Dimitrijević et al. 2001).

It is also important to consider $T$. granarium, which is a post-harvest pest of grain and cereal products in many countries. This beetle is believed to be one of the 100 most invasive pests in the world (Lowe et al. 2000). Damages due to the T. granarium may be as high as $75 \%$ (Jood et al. 1993).

Another coleopteran insect, Meligethes aeneus (pollen beetle, Nitidulidae), is considered a key pest of Brassica napus (oilseed rape). In many European countries, such as Denmark, Sweden, Switzerland, and Poland, M. aeneus causes losses of up to 60-100 \% (Heimbach et al. 2007; Kazachkova 2007; Ahmanl et al. 2009; Breitenmoser 2012; Zamojska et al. 2011). Larvae as well as adult beetles are responsible for these losses (Blight and Smart 1999).
In addition, rice has its own set of herbivorous pests belonging to Coleoptera: Dicladispa armigera (rice hispa, Chrysomelidae) and Sitophilus oryzae (the rice weevil, Curculionidae) are considered as the most destructive rice pests in Japan (Pathak and Khan 1994). In general, herbivorous insects are believed to be responsible for annual global crop production losses of $20 \%$ (Kerin 1994), whereas global losses caused by insects pests of storage products are estimated to be $25 \%$ of post-harvested grain yield (Cao et al. 2002; Philips and Thorne 2010). In addition, there are numerous other coleopteran insects that are capable of damaging various plant species. Numerous reports underline that multiple coleopteran species are developing insecticide resistance (Chen et al. 2015), which may increase further damages and losses caused by pests.

To summarize above, with high annual financial losses caused by chewing insects, including costs for pest control (for instance in the case of $D$. virgifera virgifera financial losses in Europe are estimated at 472 million Euros annually (Wesseler and Fall 2010)), it is imperative that successful pest management strategies are adopted.

\section{Insect adaptation to feeding on plants}

Host plant quality is very important for many aspects of insect's life, such as growth and reproduction (Awmack and Leather 2002). However, on the tissue surface occur various morphological structures (e.g., spines, setae, trichomes, thorns, and hairs) which may interfere with insects feeding (Garcia-Muniz et al. 1998). In addition, plant tissue may contain toxic compounds. To overcome these difficulties, insects have evolved many physiological, morphological, and behavioral adaptations that enable feeding, including the type of mouthparts, ways to maintain their grip on plant surfaces during feeding, and detoxification of plant defense compounds. Beetles may be herbivorous scavengers or predators capable of damaging foliage (Chrysomelidae) or seeds (some Curculionidae), and they can also be bark borers (Scolytidae) or nectar feeders (some Buprestidae). The mouthparts of beetles are adapted to biting or chewing. Chewing mouthparts occur in many insect orders, such as Coleoptera (beetles), Lepidoptera (caterpillars), Orthoptera, or Isoptera. Beetle larvae usually have chewing mouthparts, but there may be differences in the feeding habits of larvae and adults. Insects that possess chewing mouthparts are able to create noticeable holes in leaves, wood, or fruits.

Leaf chewers may have adapted to grip exposed leaf surfaces. Their feet usually feature hooks and hairs to help them maintain their grip. Some insects, such as the leaffeeding beetles (Chrysomelidae), have large toes with pads 
of hairs on their underside (Beutel and Leschen 2005). In terms of digestion, insects have a wide range of enzymatic activities that facilitate feeding on plants. Included among the enzymes are proteases, which are responsible for breaking down dietary proteins into simple peptides and amino acids (Terra and Ferreira 1994). Proteases are found most abundantly in the midgut region of the insect digestive track, and are subdivided into endopeptidases (proteinases) and exopeptidases. Herbivorous insects have a wide diversity of digestive proteases. It is assumed that insects in the Lepidoptera and Diptera orders generally use serine proteases, while those in the Coleoptera order use cysteine proteases (Murdock et al. 1987). However, it is important to note that each species has its own set of enzymes. In addition, the midgut $\mathrm{pH}$ depends on the species and provides the optimal condition for protease activity. Serine proteases require alkaline conditions, whereas cysteine proteases function best in an acidic environment. Aspartyl proteases often occur together with cysteine proteases, as is the case in Hypera postica (alfalfa weevil, Curculionidae) (Wilhite et al. 2000). Cysteine proteases were found in the following coleopteran families: Meloidae, Coccinellidae (Epilachna varivestis, Mexican bean beetle) (Murdock et al. 1987), Tenebrionidae ( $T$. castaneum) (Murdock et al. 1987), Bruchidae (Zabrotes subfasciatus, Mexican bean weevil) (Lemos et al. 1987), Chrysomelidae (C. maculatus and Acanthoscelides obtectus, bean weevil) (Kitch and Murdock 1986; Campos et al. 1989; Wieman and Nielsen 1988), Curculionidae, and Silphidae (Terra and Cristofoletti 1996). Serine protease activities were observed in $T$. granarium (Hosseininaveh et al. 2007) and Rhynchophorus ferrugineus (red palm weevil, Curculionidae) (Hernández et al. 2003).

Insects can also efficiently use both serine and cysteine proteases to digest proteins because of the compartmentalization of protease activities to the posterior and anterior portions of the midgut, which have different $\mathrm{pH}$ levels (Thie and Houseman 1990). For example, in Tribolium molitor (mealworm beetle, Tenebrionidae) larvae, the $\mathrm{pH}$ in the anterior midgut is 5.9, whereas in the posterior region, it is 7.9. The proteases are located in the regions with the optimal $\mathrm{pH}$ for activity. This compartmentalization of enzyme activities also occurs in T. castaneum larvae (Oppert et al. 2005). The presence of three mechanistic classes of proteases (i.e., cysteine, serine, and aspartyl proteases) was reported in Lissorhoptrus brevirostris (rice water weevil, Curculionidae) (Hernández et al. 2003), while four classes were observed in Oulema spp. larvae (Wielkopolan et al. 2015). Taking all of afore-mentioned data into account, it can be concluded that beetles are relatively similar in terms of morphological and physiological adaptations enabling feeding (mouthpart, basic organization of the digestive tract). However, the insect digestive profile (enzymes content and optimal conditions of their activities) can be very diverse. This diversity reflects beetles' adaptations to specialized niches and feeding habits. Importantly, insects digestive systems are not passive, but are able to adapt to plant toxins and antinutritional compounds.

The oral secretions of insects consist of a mixture of components that allow for feeding on plant material. Herbivorous pests are associated with various organisms and elicitors (HAOEs-herbivore-associated organisms and elicitors; Zhu et al. 2014; Bonaventure et al. 2011) that function during insect feeding. The oral secretions are diverse and may include enzymes (glucose oxidase and $\beta$-glucosidase) (Mattiacci et al. 1995; Eichenseer et al. 1999), modified forms of lipids [fatty acid and amino acid conjugates and sulfur-containing fatty acids (caeliferins)] (Alborn et al. 2007; Hilker and Meiners 2010), cell-wall fragments (pectins and oligogalacturonides) (Bergey et al. 1999), peptides from digested plant proteins (Schmelz et al. 2006), or organisms (microbes, fungi, viruses, and parasites), and/or organismderived proteins (Hughes et al. 2012) that interfere with the outcome of the plant-insect interaction. The insect elicitors are not considered as general elicitors, because they are usually restricted to a specific plant-insect interaction. Some herbivores may have effector molecules that can suppress plant defense responses (Walling 2009). In most cases, the effector molecules suppress a jasmonic acid (JA)-dependent pathway, which is mostly activated in response to herbivorous insects (Chung et al. 2013). These effector molecules may be present in insect oral secretions or eggs (Consales et al. 2012; Atamian et al. 2013) (Fig. 2). For example, L. decemlineata harbours multiple bacteria symbionts in oral secretion that can be transferred to the plant during feeding. Flagellin derived from Pseudomonas sp. induces salicylic acid (SA)-dependent pathway and suppress JA signaling pathway (cross-talk), what consequently reduces plant defense against the beetles (Chung et al. 2013).

Insects may also be associated with microbes that are pathogenic for plant. These plant pathogens not only may suppress plant response to the benefit of their insect host but may also change plant architecture and/or physiology to attract vectoring insects to increase the chances of pathogens' dispersal (Bai et al. 2009).

In conclusion, insects are not simple, but constitute very complex organisms community capable of flexible adaptations to the prevailing challenges to which insect host is exposed. Therefore, the future studies should be aimed at characterization of the compositions of particular insect communities as well as search for a factor or factors disturbing insect physiology as well as explaining their roles in plant-insect interactions. 
(a)

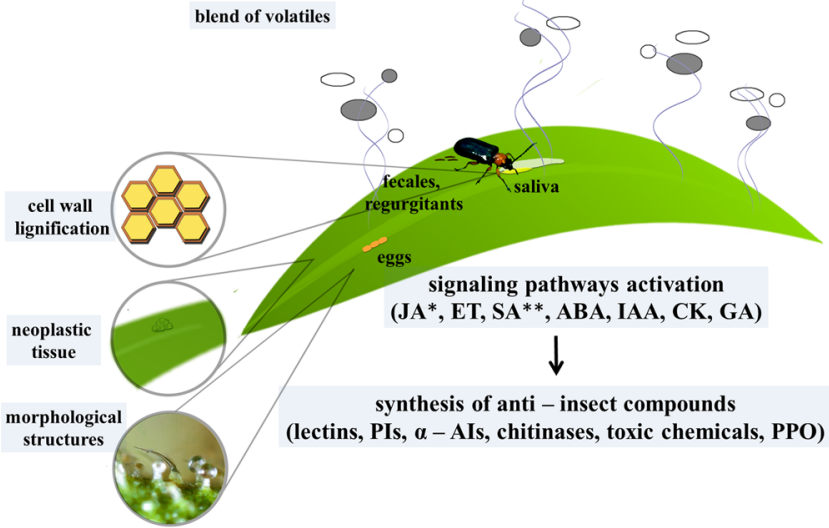

Fig. 2 Proposed scheme of plant direct and indirect responses against insects and influence of microbial factors on plant-insect interaction. a Plant direct response includes: morphological structures on the leaf surface (e.g. spines, setae, trichomes, thorns, and hairs) that may interfere with insects feeding, strengthening of the cell wall through lignification (tissue is less palatable to herbivores what inhibits insect feeding), and formation of neoplastic tissue (which inhibits pest entry into the plant). Response occurs not only in the damaged place, but the signal is transmitted to other parts of plant. Plant indirect response is associated with volatile substances emission. In response to insect feeding jasmonic acid (JA)-/ethylene (ET)-dependent pathways are activated, and thus, downstream defense response is initiated, including synthesis of antinutritional proteins [e.g. lectins, protease inhibitors (PIs), and alpha-amylase inhibitors ( $\alpha$-AIs)]. b An important role in the plant-insect interaction play 'hidden' factors, such as microbes associated both with insects and plants. Plant-associated bacteria are localized either in the rhizosphere or in the phyllosphere (stars). These bacteria may interfere with plant signaling pathways which may have positive or negative effect on insect fitness. In

\section{Plant defense strategies}

Plants respond to herbivores attack either directly or indirectly (Arimura et al. 2009) (Fig. 2). Direct plant responses inhibit insect processes, such as reproduction or digestion, while also contributing to improved mechanical protection on plant surfaces (e.g., spines, setae, trichomes, thorns, and hairs). The plant cell wall is considered the first line of defense. In response to an attack by herbivorous insects, the cell wall is strengthened through a lignification process, which makes tissue less palatable to herbivores and inhibits insect feeding (Garcia-Muniz et al. 1998) (Fig. 2a). These plant responses ultimately disturb the biological activities of the attacking insects, thereby leading to some protection from damage. Plants produce chemicals (e.g., terpenoids, alkaloids, anthocyanins, phenols, quinones, flavones, and isoflavones) (Hanley et al. 2007; Engelberth 2006) or proteins (e.g., PR proteins) that are toxic to insects. Ryan (2000) categorized plant proteins newly synthesized after (b)

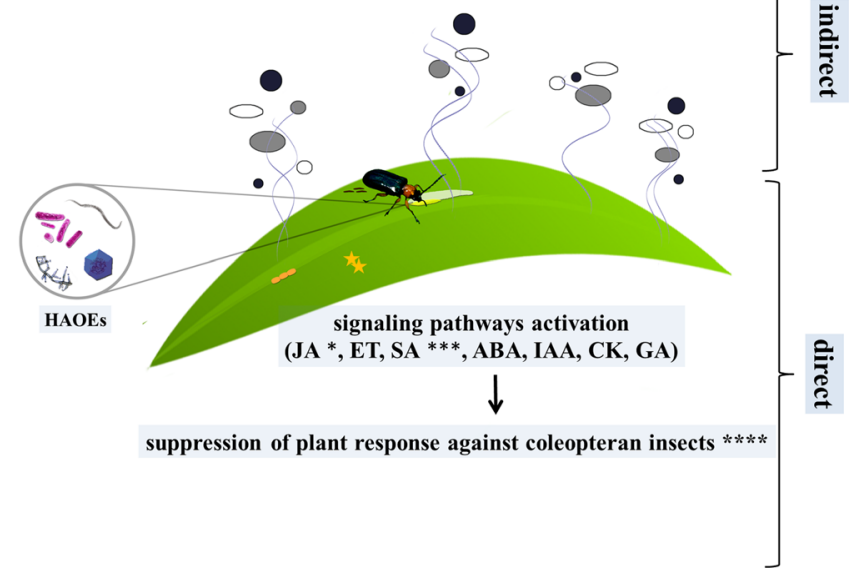

addition, some plant-associated microbes may produce toxins that act as bioinsecticides. On the other hand, beetles-associated organisms and elicitors having contact with plant tissue during insect feeding act as modulators and modificators of plant defense response to the benefits of their insect hosts. For instance, microbes may modify plant response what leads to alterations in plant volatiles composition (circles) and defense-related molecules expression. Insects-associated microbes may shift plant response from JA-dependent to salicylic acid (SA)-dependent pathway. Asterisk JA is considered as the most important regulators in plant defense against insects (Watanbae et al. 2001; Howe and Jander 2008; Pieterse et al. 2012). Double asterisk SA is less important in plant response to chewing insects. Triple asterisk degree of SA involvement in plant response is dependent on the composition of insect-associated bacteria. Four asterisk bacteria contribution in the suppression of the plant response against Coleoptera was proposed in research papers (including Barr et al. 2010; Chung et al. 2013). $A B A$ abscisic acid, $I A A$ indole-3-acetic acid, $G A$ gibberellic acid, $C K$ cytokinin, HAOEs herbivore-associated organisms and elicitors, $P P O$ polyphenol oxidase

wounding into three groups: (1) antinutritional proteins or defensive proteins (e.g., PIs) or proteins involved in secondary compound biosynthesis, (2) signaling pathway proteins, and (3) proteins involved in rerouting metabolic activities to the production of defensive compounds, such as proteases. Some plants are able to accumulate and store toxic compounds to ensure an immediate response to attacking herbivorous insects. Plants that do not accumulate defensive compounds may minimize damage through rapid growth (Jander et al. 2001).

A unique plant response to coleopteran insect feeding may involve the formation of neoplasmic tissue that impedes larval entry into the plant host (Doss et al. 2000) (Fig. 2a). In addition, during oviposition, some elicitors that may influence plant responses are produced. For example, fatty acids, such as bruchins, which are $\alpha, \omega$-diols esterified at one or both oxygens with 3-hydroxypropanoic acid, derived from B. pisorum and C. maculatus are considered potential regulators of neoplastic growth of pea 
pods. In addition, bruchin $\mathrm{B}$ can up-regulate the expression of $C Y P 93 C 18$, leading to an increased production of pisatin and isoflavone phytoalexin, which are involved in plant defense mechanisms (Cooper et al. 2005). Furthermore, callus formation inhibits larval entry into the pods (Doss et al. 2000). Plants protect themselves against biotic and abiotic stresses with a highly sophisticated network of signal transduction pathways, which are regulated by different hormones (Pieterse et al. 2012). Phytohormones may also affect plant interactions with beneficial organisms, such as microbes (Gutjahr and Paszkowski 2009; Hause and Schaarschmidt 2009).

Plant responses can be categorized as systemic acquired resistance (SAR) or induced systemic resistance (ISR). In general, ISR is associated with defense against pests, and may be induced by nonpathogenic bacteria, abiotic factors or feeding by herbivorous insects (Watanabe et al. 2001; Galzebrook 2005; Howe and Jander 2008). ISR is associated with signaling pathways dependent on jasmonic acid (JA) or ethylene (ET). In SAR, plants are protected against infection by a wide range of pathogens. The activation of SAR requires endogenous salicylic acid (SA) and its functional metabolites. SA is associated with plant defense against biothropic pathogens (Glazebrook 2005) and phloem-feeding herbivores (Kaloshian and Walling 2005). Importantly, SA involvement is believed to be greater in plant response against piercing and sucking type of insects pests than the chewing insects (War et al. 2012; Zhao et al. 1996). JA, SA (Pieterse et al. 2012), and ET (Adie et al. 2007) are considered as the fundamental regulators of plant defense response against attackers (Pieterse et al. 2012). The main role of hormones is a reprogramming of plant genetic machinery that leads to the adequate plant response to external stressors. Interaction between individual components of a highly sophisticated network of signal transduction pathways can be additive, antagonistic, or synergistic. Ethylene pathway is activated, likewise JAmediated pathway, in response to necrotrophic pathogens and often works synergistically with JA (Chen et al. 2005; Von Dahl and Baldwin 2007). It is considered that JA and SA are effective against different groups of insects and pathogens. The cross-talk between these two main signaling pathways (SA, JA) allows plants to fine-tune defense responses (Thaler et al. 2012). In general, it is considered that SA acts antagonistically to the JA-pathway (Spoel et al. 2003). This trade-off can occur when plant is attacked simultaneously by various pathogens (Koornneefer et al. 2008). Others plant phytohormones, such as abscisic acid (ABA), auxins [indole-3-acetic acid (IAA)], cytokinin (CK), or gibberellic acid (GA) (Robert-Seilaniantz et al. 2011; Torres-Vera et al. 2014) act as secondary players and modulators of main signaling pathways. For instance, ABA has a primary role in the regulation of plant defenses against abiotic stressors. It may also play a role in plant responses against pathogens (Beattie 2011; Ton et al. 2009) or herbivores (Erb et al. 2009; Verhage 2011), as it may affect multiple signaling pathways.

Herbivorous insects, including coleopteran ones, can evade plant response through employing some factors, such as bacteria, obligate pathogens that are able to suppress JAdependent defenses. In effect, plant recognizes beetles as microbes and is not able to induce effective response against these insects (Chung et al. 2013).

After induction of defense signaling pathways, the plant is able to synthesize the group of antinutritional proteins that can reduce the ability of insects to digest plant material. This group of antinutritional proteins belong to , e.g, protease inhibitors (PIs), alpha-amylase inhibitors ( $\alpha$-AIs), lectins, chitinases, and polyphenol oxidases (PPO) (Fig. 2a). The up-regulation of these proteins was frequently observed during Coleopetera-plant interactions as stated below.

Agglutinin and arcelin, which are lectins (sugar-binding proteins) from Phaseolus vulgaris, are toxic to C. maculatus (Gatehouse and Gatehouse 1998) and Z. subfasciatus, respectively (Osborn et al. 1988). In addition, Talisia esculenta (Sapindaceae) lectins showed anti-insecticidal activity against $C$. maculatus and $Z$. subfasciatus larvae (90 \% mortality). Allsopp and McGhie (1996) reported that snowdrop and wheat germ lectins can suppress the growth of Antitrogus parvulus (sugarcane white grub, Scarabaeidae) larvae. Agglutinin from wheat germ inhibits larval growth of Diabrotica undecimpunctata howardi (southern corn rootworm, Chrysomelidae) (Czapla and Lang 1990). Canatoxin isolated from Canavalia ensiformis (jack bean, Fabaceae) had a toxic and lethal activity against insects with cathepsin-based digestion. It caused complete inhibition of C. maculatus larval growth (Carlini et al. 1997).

PR proteins warrant particular attention, especially the PIs of PR-6. The PIs naturally occur in plant leaves and storage organs and their abundance significantly increases in response to wounding (Sharma 2015), which suggests their important roles in plant defense. The PIs help to regulate plant protease activity affecting plant developmental processes, such as programmed cell death (Pernas et al. 1999) or protein mobilization in storage tissue. It is important to note that PIs are considered effective against pests, because they inhibit digestive proteases in the insect gut. The disruption of digestive processes negatively influences insect growth and development. The PIs can also affect a number of other vital processes, such as proteolytic activation of enzymes and molting (Sharma 2015). For example, the gene encoding the cysteine PI, oryzacystatin, which inhibits cysteine proteases in the digestive track of Chrysomela tremulae (poplar leaf beetle, Chrysomelidae), was transformed into transgenic poplar plants. Feeding 


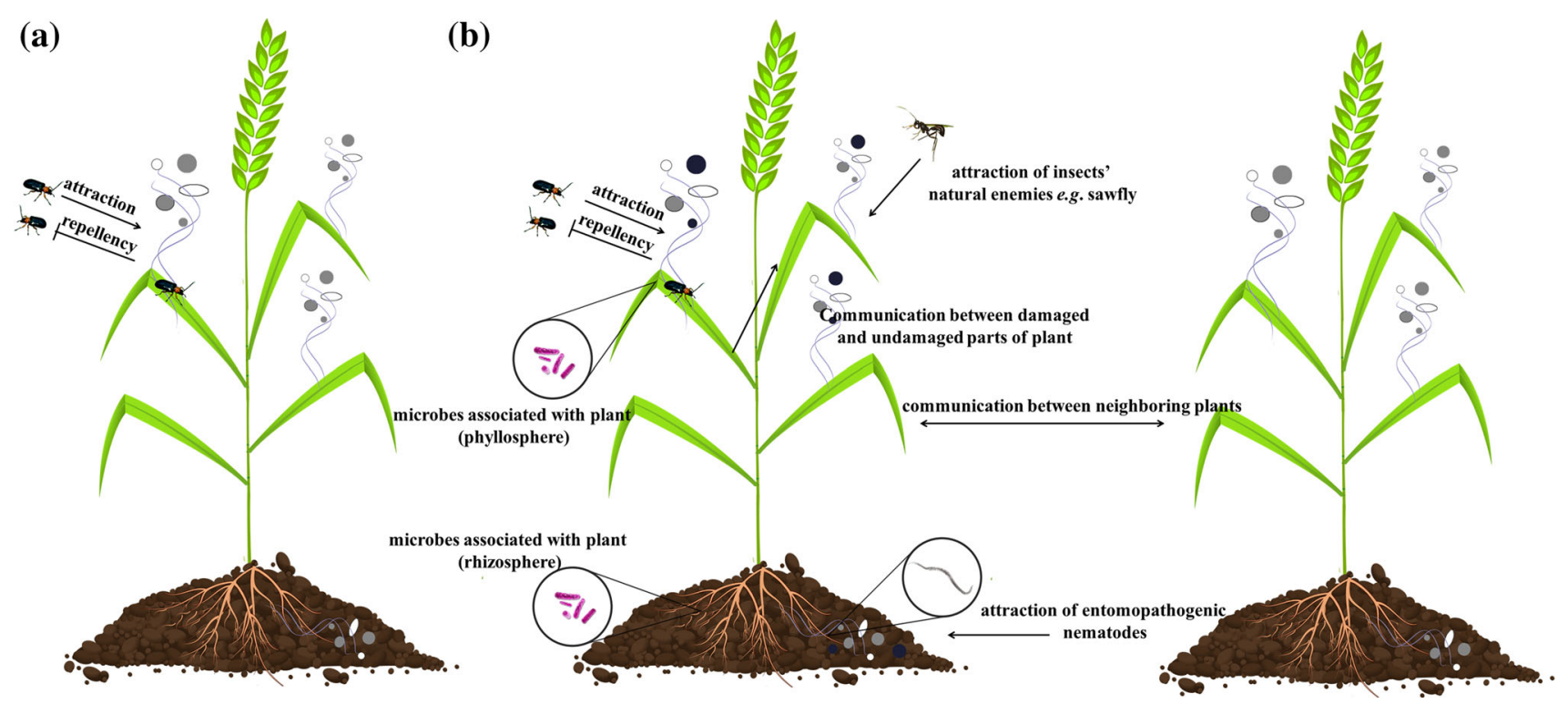

Fig. 3 Volatiles emission during plant-insect interactions. a Plant releases the blend of volatiles (different colored circles) that may repel plant pests and attract beneficial insects (e.g. pollinators). However, some plant pests are also attracted by plant volatiles. b Plants are able to recognize differences between mechanical wounding and insects feeding what results in a different composition of volatiles compounds. The plant, wounded by insect feeding, may emit volatiles which attract pests' natural enemies (parasites,

tests indicated that the transgenic plants highly expressing oryzacystatin were toxic to $C$. tremulae larvae (Leplé et al. 1995). On the other hand, the trypsin-papain inhibitor PdKI2 of Pithecellobium dumosum (Fabaceae) seeds effectively inhibited the digestive proteases of the bruchids Z. subfasciatus and C. maculatus (Oliveira et al. 2007). The proteinaceous Kunitz-type trypsin inhibitor from Crotalaria pallida (Fabaceae) seeds, CpaTI, inhibited the digestive enzymes of $Z$. subfasciatus, $C$. maculatus, and Anthonomus grandis (boll weevil, Curculionidae) to varying degrees (Gomes et al. 2005). A serine PI from Amaranthus hypochondriacus (Amaranthaceae) actively suppressed the proteolytic activity of chymotrypsin and trypsin from Prostephanus truncatus (larger grain borer, Bostrichidae) (Houseman and Thie 1993).

In plant defense responses, $\alpha$-AIs, which are plant PR proteins, also play important roles. Wheat $\alpha$-AIs may inhibit $\alpha$-amylase enzymes in Tenebrio obscurus (mealworm, Tenebrionidae), Tribolium spp. (flour beetle, Tenebrionidae), Sitophilus spp. (wheat weevils, Curculionidae), and Oryzaephilus spp. (grain beetle, Silvanidae). In addition, $\alpha$-AIs protect transgenic peas from B. pisorum (Morton et al. 2000).

On the other hand, chitinases that also belong to PR proteins, digest chitin which is a component of insect exoskeletons and peritrophic membranes (Kramer et al. 1997). Transgenic Solanum lycopersicum (Solanaceae) predators, including entomopathogenic nematodes), repel herbivorous insects (including Coleoptera), induce defense responses in neighboring plants as well as function in the communication between damaged and undamaged parts of plant. In addition, microbes associated both with plants (enlarged circles in the rhizosphere and phyllosphere) and insects may modulate plant volatiles composition. Moreover, insect-associated pathogens of plants may modulate plant physiology to attract their potential insect vectors

overexpressing the WIN6 chitinase was observed to be resistant to $L$. decemlineata attack (Lawrence and Novak 2006).

Plant defense responses to insect feeding occur not only at or near the site of damage, but also throughout the plant because of signaling molecule-based communication between different plant parts (Fig. 3). A systemic and local response may result in the production of the same defensive proteins, but there may be differences in the kinetics of their production. For example, PIs are produced because of induced defense responses, but may also accumulate as part of constitutive defense responses. Phytoecdysteroids (defense compounds) accumulate in Spinacia oleracea (spinach, Amaranthaceae) foliage and their synthesis is upregulated in response to tissue damage caused by $O$. sulcatus (Schmelz et al. 1999). Similarly, there is an increase in glucosinolate content in response to feeding by Psylliodes chrysocephala (cabbage stem flea beetle, Chrysomelidae) (Bartlet et al. 1999). Therefore, plant defense compounds accumulate before insect feeding, and herbivory induces the synthesis of these compounds at a higher rate (Garcia-Olmedo et al. 1987; van Dam et al. 2001).

Indirect responses to insects are mediated through the release of a mixture of volatiles, which may attract predatory and parasitic insects that are natural enemies of herbivores (De Moraes et al. 2001; Dicke et al. 2003), repel 
herbivores (Kessler and Baldwin 2001), induce defense responses in neighboring plants or function in the communication between damaged and undamaged parts of a plant (Karban et al. 2000; Engelberth et al. 2004) (Fig. 3). Plant volatile emission can be, however, a double sword, because they also attract plant pests which feed on these plants. The release of volatiles may have some detrimental effects for plants. There is evidence showing that certain inducible plant volatiles can attract coleopteran insect pests. For example, the $L$. decemlineata is attracted to plants by a mix of volatiles and methyl jasmonate (Dickens 2006). Volatiles released by Ipomoea batatas (sweet potato) attract Cylas formicarius (sweet potato weevil, Curculionidae) (Korada et al. 2010). Moreover, von Mérey et al. (2011) observed that D. virgifera virgifera beetles occur more frequently in fields treated with green leaf volatiles, which suggests the volatiles have a role in attracting the beetles. It was also observed that the beetles prefer the leaves of Vitis labrusca and Malus spp. infested by Popillia japonica (Japanese beetle, Scarabaeidae) over undamaged leaves (Loughrin et al. 1995, 1996). Plant volatiles may also mediate the interaction among plants, insects, and microbes (Dicke and Baldwin 2010). They are released in large amounts during attacks by herbivores (Turlings et al. 1995; Tumlinson et al. 1999). Noge et al. (2011) reported the emission of plant volatiles [phenylacetonitrile, (E)- $\beta$-ocimene, linalool, (E)-4,8-dimethyl1,3,7-nonatriene, and (E,E)- $\alpha$-farnesene] from the leaves of Fallopia sachalinensis (giant knotweed plants) during a $P$. japonica attack. Interestingly, in the case of this insect, plant volatiles were not emitted from either undamaged leaves or leaves that were mechanically wounded. These results suggest that the synthesis of volatiles is induced de novo in $F$. sachalinensis by an elicitor contained in the oral secretions of $P$. japonica. Noticeably, it is considered that terpenoids, such as (E)- $\beta$-farnesene, play a key role to the attraction natural enemies of insects. (E)- $\beta$-farnesene is considered as principal component of the alarm pheromone of many aphid species (sap-sucking insects) (Beale et al. 2006; Al Abassi et al. 2000; Pickett et al. 1992). In general, it is assumed that plants are able to differentiate between herbivore damage and wound response by emission of certain types of volatile substances during feeding, which are not present during only mechanical wounding (Delphia et al. 2006) (Fig. 3b). Volatiles emission and their attraction of pest's natural enemies were also studied for other beetles. For example, Zea mays roots attacked by D. virgifera virgifera larvae release the sesquiterpene (E)- $\beta$ caryophyllene, which attracts Heterorhabditis megidis entomopathogenic nematodes that feed on the larvae (Rasmann et al. 2005). Genetically modified maize plants that constitutively produce (E)-caryophyllene attract nematodes more effectively than wild-type controls, resulting in reduced root damage caused by $D$. virgifera virgifera larvae (Degenhardt et al. 2009). Similarly, when Thuja occidentalis is attacked by Otiorhynchus sulcatus (black vine weevil, Curculionidae), it releases volatiles from the roots, which also attract the entomopathogenic nematode $H$. megidis (van Tol et al. 2001).

In conclusion, plants are able to recognize mechanical wounding from damage caused by insect feeding and produce plant volatiles of different compositions. Plants are sessile and as such they are in a worse position, because they can not escape from insects, especially so well adapted to feeding as Coleoptera. Nonetheless, plants have developed a series of defense mechanisms allowing them to (a) defend themselves (a series of defense events, from recognition to attack), (b) to warn their neighbors against danger (releasing a blend of volatiles), (c) to attract insect natural enemies. As mentioned above insects have adopted to diverse plant defense mechanisms. On the other hand, plants also developed various adaptations to insects attack what further resulted in the genetic variation of insects pests. What is noticeable, plants likewise insects have hidden players-microorganisms that may have a considerable impact on the outcome of this ongoing plant-insect battle which will be discussed below.

Based on the current knowledge we can deduce that plant volatiles may be used to develop new, environmentally friendly strategies for crop protection in the future. First, volatiles may be used to enhance the attractiveness of crop plants to biological control agents what was confirmed by field studies (e.g. Degenhardt et al. 2009). Secondly, they may be used to develop trap crops (attraction of pests). Therefore, the knowledge of the plant volatiles composition is very important as well as the analysis of the possibility of plant volatiles application as effective method of limiting pest harmfulness and thus economic losses.

\section{Insect reactions to plant defense}

During feeding, insects may consume harmful substances, such as plant defense compounds. Plant-derived toxins may have a broad range of activities and exhibit highly diverse molecular structures and physical properties. The concentration of these compounds depends on the organs in which they are produced and the plant developmental stage (Gebrehiwot and Beuselinck 2001). Plant defense compounds have forced herbivores to evolve strategies that enable them to recognize and avoid these compounds to prevent ingestion of lethal doses. These strategies can be genetically determined, inherited, or learned (Chapman 2003; Després et al. 2007; Schowalter 2011). Coleopteran insects may avoid the effects of plant toxins through behavioral, physical, and biochemical mechanisms, including the 
production of detoxification enzymes, such as esterases, glutathione- $S$-transferases, and cytochrome $\mathrm{P} 450$ monooxidases ( $\mathrm{Li}$ et al. 2007). They may also adapt to the toxic compounds or avoid ingestion of toxic substances by feeding on non-toxic plant organs or during developmental stages where toxins are absent (Hoy et al. 1998; Després et al. 2007). Insects may also feed on different plant hosts to avoid lethal doses of plant defense compounds (Pankoke et al. 2012). There are numerous reports showing how coleopteran insects deal with plant toxic substances. For example, the specialist beetle E. varivestis has reduced endogenous $\beta$-glucosidase activities compared with the generalist locusts (grasshopper, Acrididae). During feeding, the beetles hydrolyze more cyanogenic glucosides than the locusts because of differences in how the insects feed. Beetles (leaf-chewing) have relatively small mandibles that force them to chew leaves and crush plant tissue, but locusts (leaf-snipping) have larger mandibles that allow them to consume larger leaf pieces, resulting in a higher percentage of plant tissue being ingested and more limited hydrolysis of cyanogenic glucosides (Ballhorn et al. 2010). Insects may sequester toxic plant compounds. Some plants (crucifer plants, Brassicales) are equipped with the glucosinolate-myrosinase ("mustard-oil bomb") defensive system which is activated during insect attack. Some beetles, such as Phyllotreta striolata (striped flea beetle, Chrysomelidae) avoid this system throughout selective accumulation of substrate (glucosinolate) that is activated by their own myrosinase (Beran et al. 2014). Some insects are able to consume and accumulate plant defense compounds in their tissues, such as the hemolymph or defense glands (Nishida 2002; Optiz and Muller 2009). Insects that sequester toxic phytocompounds may be toxic to their own predators (Discher et al. 2009). For example, leaf beetles, such as Chrysomela populi (broad-shoulder leaf beetles, Chrysomelidae) and Phratora vitellinae (brassy willow beetle, Chrysomelidae) sequester the salicinoid salicin from Salix spp. (Salicaceae) and transport it from the gut to the hemolymph and finally to the defense glands (Kuhn et al. 2004; Burse et al. 2009). $\beta$-Glucosidases hydrolyze the salicin to saligenin, which acts as a deterrent to predators (Kuhn et al. 2004; Optiz and Muller 2009). Additionally, Chrysomela lapponica (leaf beetle, Chrysomelidae) larvae that feed on plants from the Salicaceae family (e.g., willow and poplar trees) sequester plant-derived salicin and other leaf alcohol glucosides, which accumulate in their defensive glands and are modified to bioactive compounds (Burse et al. 2009).

The detrimental effects of inhibitors on insects have been well documented. The negative effect of cysteine PIs on the growth of certain coleopteran species was shown years ago (Orr et al. 1994). The L. decemlineata uses cysteine and aspartyl proteases (Michaud et al. 1993). As demonstrated using the synthetic inhibitor E-64 (transepoxysuccinyl-L-leucylamido(4-guanidino)butane), cysteine PIs significantly inhibit $L$. decemlineata larvae growth (Wolfson and Murdock 1987). Additionally, cysteine PIs have been shown to affect the protease activity of coleopteran larvae, such as those of D. undecimpunctata howardi (Fabrick et al. 2002) or the D. virgifera virgifera (Zhao et al. 1996). Generally, pests have evolved different adaptations to reduce the harmful activities of PIs. They may increase digestive enzyme activity, synthesize more resistant proteases (Paulillo et al. 2000), digest inhibitors in the gut (Girard et al. 1998), decrease the sensitivity of their enzymes to inhibitors (Brito et al. 2001). For example, proteases of $Z$. subfasciatus are capable of degrading an $\alpha$ AI from the common bean (Ishimoto et al. 1996). The soybean cysteine PI soyacystatin $\mathrm{N}(\mathrm{scN})$ is capable of suppressing the digestive enzymes of herbivorous insects and can inhibit the growth and development of C. maculatus, $L$. decemlineata, and D. virgifera virgifera (Zhao et al. 1996; Koiwa et al. 1997; Zhu-Salzman et al. 2003). $C$. maculatus has evolved counter-defensive strategies against $\mathrm{scN}$, such as increasing the expression of scN-sensitive and $\mathrm{scN}$-insensitive enzymes and hydrolyzing scN (Zhu-Salzman et al. 2003). Oppert et al. (2004) reported that $T$. castaneum larvae have evolved mechanisms to overcome dietary inhibitors. Although larvae of this pest produce cysteine and serine proteases, cysteine proteases are the major digestive proteases. Serine and cysteine PIs alone had minimal effects on larvae development and protease activity because the digestive preferences were switched from cysteine protease-based to serine protease-based digestion. Larval growth was inhibited when both cysteine and serine PIs were present. Additionally, Zhu-Salzman et al. (2003) indicated that $T$. castaneum responds to cysteine PIs by increasing the production of aspartic proteases. However, the L. decemlineata responded to cathepsin D inhibitors in transgenic plants by decreasing the production of inhibitor-sensitive enzymes (Brunelle et al. 2004). Further, in Oulema spp. larvae that were fed the synthetic serine PI AEBSF (4-(2-aminoethyl)benzenesulfonyl fluoride hydrochloride), two additional protease activities were observed (Wielkopolan et al. 2015).

Interestingly beetles may also use proteases of endosymbiotic bacteria inhabiting their gut, what can lead to the change of insect's food preferences (adaptation of insect to a new host plants) (Chu et al. 2013; Shao et al. 2012). For instance, in this way D. virgifera virgifera adapted to feeding on the non-host plants, such as soybean (Glycine max), which was introduced into the corn field for crop rotation (Chu et al. 2013).

Presented examples of beetles adaptation to inhibitory or toxic plant compounds showed that when the insects were exposed to one class of PIs, they shift to the production of a 
different class of proteases. When more than one class of PIs was present, then the larvae were unable to adapt using another class of proteases. As mentioned above insects digestive system is not passive but flexible. Profile of insect's digestive enzymes may undergo changes in response to plant anti-feeding substances (e.g. PIs). To all these afore-mentioned adaptations of beetles considerably contribute insect-associated microorganisms.

\section{Insects as a well-organized community}

Insects harbor for a large array of microbes so they cannot be considered as individuals but as a community. The microorganisms inhabiting the insect gut may include viruses, parasitoid larvae, bacteria, parasitic worms, and fungi (Hughes et al. 2012). Insect-associated organisms not only affect reproduction, digestion, morphology, and behavior, they may also modify plant defense mechanisms for the benefit of their insect host. As mentioned above gut microorganisms can also significantly affect insect evolution by influencing adaptations to specialized niches and feeding habits.

Fungi are frequently observed in the guts of insects that feed on wood or detritus, and are believed to be involved in digestion. For example, many subcortical insects, such as bark beetles (Curculionidae) have fungal symbionts that confer a variety of benefits to the insect (Douglas 2009). In Anoplophora glabripennis (Asian longhorned beetle, Cerambycidae), lignin degradation may occur primarily because of fungal activities (Geib 2008). However, in this review, we focus only on coleopteran insect-associated bacteria.

Studies have revealed that the bacteria inhabiting the insect gut are largely nonpathogenic and in most cases positively affect the insect host. They may affect digestion (Koga and Tsuchida 2003), reproduction (White et al. 2009), defense against natural enemies (e.g., predators and parasites) (Oliver et al. 2010), or genetic differentiation (Charlat et al. 2009). They may also function as elicitors or effectors and modify interactions between plants and insects to favor the insect host. There are a variety of bacterial phyla represented in the insect gut, including: Gammaproteobacteria, Alphaproteobacteria, Betaproteobacteria, Bacteroidetes, Firmicutes (Lactobacillus and Bacillus), Clostridia, Actinomycetes, Spirochetes, Verrucomicrobia, and Actinobacteria (Colman et al. 2012). However, each insect species has its own set of associated organisms, which is influenced by the secondary compounds consumed in the diet (Kohl and Dearing 2012) and this diet is extremely diverse in the case of beetle species. For example, beetles of $D$. virgifera virgifera are associated with endosymbiotic Wolbachia spp. and enterobacteria (Barr et al. 2010). Wolbachia spp. are present intracellularly throughout the insect body, including in the salivary glands and reproductive tissue, where they are found at high concentrations. It is estimated that Wolbachia can be associated with $20-70 \%$ of all insects species (Jeyaprakash and Hoy 2000; Zug and Hammerstein 2012). It has been reported that Wolbachia may protect the host from pathogens (Eleftherianos et al. 2013), restore or affect fertility or overcome plant defense response (Starr and Cline 2002) (Barr et al. 2010). For example infection of $T$. castaneum with Wolbachia causes cytoplasmic incompatibility and reduced fertility of infected $T$. castaneum females was observed (Wade and Chang 1995). In addition, females of $T$. castaneum without bacteria Wolbachia lay sterile eggs although they were mated with infected males (Wade and Stevens 1985). The larvae of L. decemlineata can be associated with symbionts belonging to the genera Stenotrophomonas, Pseudomonas, and Enterobacter (Chung et al. 2013) as well as with Flavobacterium endosymbionts (Krawczyk et al. 2015). Symbionts inhabiting the insect gut can be vertically transmitted. For example, microbes present in the cytosol of the foregut cells of grain weevil larvae (Sitophilus) migrate to the midgut epithelial cells in adults (Dale et al. 2002). The symbiont of Macroplea appendiculata and $M$. mutica (reed beetles, Chrysomelidae) is also vertically transmitted (Kölsch et al. 2009). The abundance of bacteria inhabiting the insect gut is affected by $\mathrm{pH}$ or the production of enzymes, including lysozymes, such as peptidoglycan hydrolases, which digest bacterial cells (Dubreuil et al. 2001). Some insects are able to control symbionts because of the presence of antimicrobial peptides. For example, Sitophilus zeamais (maize weevil, Curculionidae) uses the antimicrobial peptide coleoptericin A to inhibit endosymbiont cytokinesis by limiting bacterial cell division and dispersion (Login and Heddi 2012). Microbes associated with herbivorous insects can also protect their host against fungal species. Based on the results of controlled assays, microbes in the oral secretions of Dendroctonus rufipennis (spruce beetle, Scolytinae) were observed to inhibit the growth of fungal species responsible for reducing spruce beetle reproduction and survival (Cardoza et al. 2006).

Insect gut microorganisms may also be involved in the detoxification of food. Some sources of nutrients are available only if the associated toxins can be neutralized. Insect-associated microbes can metabolize insecticides (Kikuchi et al. 2012), heavy metals (Senderovich and Halpern 2013), and plant defense chemicals (Boone et al. 2013; De Fine Licht et al. 2013; Hammerbacher et al. 2013). For example, symbiotic yeast in the gut of Lasioderma serricorne (cigarette beetle, Anobiidae) can degrade dietary toxins and increase host resistance (Dowd and Shen 1990). In large numbers, Dendroctonus ponderosae 
(mountain pine beetle, Curculionidae) can kill healthy conifers (Blomquist et al. 2010) even though the trees may possess toxic compounds, such as monoterpenes and diterpene acids (Raffa et al. 2005). Boone et al. (2013) reported that bacteria (Serratia, Pseudomonas, Rahnella, and Brevundimonas) associated with D. ponderosae are able to metabolize monoterpenes and diterpene acids. For instance Serratia reduced concentration of all monoterpenes applied to media by 55-75\% (except $\alpha$-pinene).

Interestingly, symbionts that manipulate plant defense response to the benefit of their insect host may also affect other herbivores sharing the same plant. For instance fungal Grosmannia clavigera associated with $D$. ponderosae facilitate them feeding on the Pinus banksiana (jack bean). Feeding on plants by beetles inoculated with this fungus stimulate the increase of concentration of monoterpenes in the needles of the plant. In result, Choristoneura pinus (jack pine budworm, Tortricidae) feeds more, probably to compensate for decline of food quality (Colgan and Erbilgin 2011). Hence, symbiotic partner is also able to reduce food quality for its interspecific competitor.

Symbionts of insects have also impact on the levels of insects' proteolytic enzymes (Visôtto et al. 2009), carbohydrate metabolism, enhancement of nutrient absorption (Engel et al. 2012), protein synthesis (Burnum et al. 2011), and proteases production (Rao et al. 1998). Coleopteran insects may acquire new capabilities from their symbionts via horizontal gene transfer. For example, some beetles acquired plant cell wall-degrading enzymes (PCWDE) from fungi or bacteria. For instance, $\beta$-fructofuranosidases (breaking down plant sucrose enzyme) were obtained by some Coleoptera throughout horizontal transfer, probably from bacteria. The synthesis of $\beta$-fructofuranosidases in insects' cells (Pedezzi et al. 2014; Keeling et al. 2013) enables them to use plant sucrose more efficiently. On the other hand, Pauchet et al. (2014) indicated that woodboring larvae (Apriona japonica, Cerambidae) produced arsenal of PCWDEs to the degradation hemicelluloses and celluloses in wood material. Herbivorous insects can also benefit from the presence of plant pathogen. For example, plant host responses specific for a bacterial infection may disrupt the induction of defense responses against insects (Thaler et al. 2012). In this way, activated is the signaling pathway which is antagonistic to the one activated in response to insect feeding. Consequently, the expression of genes encoding molecules that affect insect physiology is suppressed (Fig. 2b).

It is unavoidable for insect to acquire during feeding the plant material without phyllosphere microbes (both pathogens and non-pathogens), but, nonetheless, large part of non-entomopathogenic plant bacteria is killed by the alkaline gut $\mathrm{pH}$, digestive enzymes, and redox potential (reactive oxygen species) or the ionic strength of the insect midgut (Vallet-Gely et al. 2009). Some evidences indicate that phyllosphere bacteria may colonize insect gut as well (Tang et al. 2012; Mason and Raffa 2014). The bacteria composition depends on plant species and genotype (Mason et al. 2015; Broderick et al. 2004). It is considered that the diversification and evolutionary success of Coleoptera have also depended on relationship with beneficial microorganisms, which have huge impact for many aspects of insect life. We are at the beginning of understanding how insect microorganisms manipulate plant response. It is important therefore to continue studies on insect- and plant-associated organisms because manipulating with symbionts and their content may be exploited to improve pest control in the future.

\section{Modification of plant defenses by coleopteran insect-associated bacteria}

The differences in plant responses to mechanical wounding and wounding by insect feeding are mainly because of the presence of HAOEs. In addition, the application of insect oral secretions to a wound can induce a plant response similar to the one activated by herbivores attack (Lawrence et al. 2008; Erb et al. 2009). The microbes present in insect oral secretions are likely largely responsible for inducing the plant responses. The modification of plant response to insect feeding by insect-associated bacteria becomes more and more studied for coleopteran insect-plant models. Previous studies indicated that the application of oral secretions from L. decemlineata larvae to mechanically wounded plant tissue suppressed plant defense responses, when compared with control plants (application of water on the wounded plants) (Lawrence et al. 2007; 2008; Chung and Felton 2011). Chung et al. (2013) analyzed whether microbes in insect oral secretions could modify plant responses to benefit of the beetles. They examined antibiotic-treated and untreated $L$. decemlineata larvae. In the case of the challenge of the plant by untreated larvae, the expression of JA-dependent genes, such as polyphenol oxidase $(P P O F / B)$ and cysteine PI, were down-regulated, while SA-dependent genes were up-regulated $(P R 1,4)$. The symbiotic bacteria associated with $L$. decemlineata larvae were responsible for the down-regulation of these genes and increased $L$. decemlineata larvae performance. The neonate larvae that fed on leaves damaged by untreated larvae gained more weight than the larvae that fed on leaves damaged by antibiotic-treated larvae due to probably suppression of synthesis of plant antinutritional proteins by insect-associated microbes. Results from experiments in which bacteria isolated from $L$. decemlineata larval oral secretions were applied to wounded plants confirmed that symbionts belonging to the genera Stenotrophomonas, Pseudomonas, and Enterobacter are 
responsible for plant defense suppression. These results suggest that plant defense responses are directed against the microbes, and help to explain how the $L$. decemlineata is able to overcome plant defense responses. Therefore, microbes associated with herbivorous insects are believed to induce signaling pathways (SA and JA cross-talk) differently from the response induced by insect feeding (e.g., L. decemlineata), (Chung et al. 2013) shifting the plant response in the direction of SA pathway rather than JA-pathway activation.

Barr et al. (2010) assessed whether insect-associated organisms could modify the interaction between plants and insects. They used antibiotic-treated and untreated D. virgifera virgifera larvae and observed that untreated larvae down-regulated most plant defense genes compared with antibiotic-treated larvae and controls. The expression of the following genes was down-regulated: glutathione- $S$-transferase (responsible for detoxification of harmful substances derived from insects or bacteria), shikimate kinase (involved in synthesis of aromatic compounds, which may inhibit insect feeding and attract insect predators) (Pare and Tumlinson 1999), lipoxygenase, and lipoxygenase-related proteins (involved in the production of oxylipins and protease inhibitors) (Kessler et al. 2004). A decrease in the expression of genes encoding cinnamoyl-CoA reductase and cinnamyl alcohol dehydrogenase, which are involved in strengthening the plant cell wall by lignification, was also observed in maize. As a result, plant tissue remained palatable and digestible for insects, and larvae could easily burrow into the root tissue. In addition, the down-regulation of genes encoding glycoproteins weakened the plant cell wall (Garcia-Muniz et al. 1998).

During insect feeding, plants must coordinate the defense responses induced by wounding and HAOEs. Unfortunately, how the effectors in oral secretions modify plant defenses to benefit herbivorous insects is not fully understood. Further studies are necessary to provide deeper insights into how insect oral secretions affect plant defense responses.

\section{Plant microbes and their impact on plant defense responses}

Microbes associated with plants may have positive, negative, or neutral effects on their hosts. The relationship between plants and microbes is usually based on mutualism. In most cases, beneficial microbes are located in the rhizosphere [plant growth-promoting rhizobacteria (PGPR), which can affect plant productivity] (Lugtenberg and Kamilova 2009) but there are also bacteria, such as endophytes that colonize the phyllosphere (Berendsen et al. 2012). The most common endophytic taxa inhabiting plant tissue are Proteobacteria (Azospirillum, Enterobacter,
Pantoea, and Pseudomonas), Bacteroidetes (Flavobacterium), and Firmicutes (Bacillus) (McInroy and Kloepper 1995). For example, in the stem of pea plants, the most frequently observed bacteria were Pantoea agglomerans and Pseudomonas fluorescens. Less frequently observed were Pseudomonas viridiflava and Bacillus megaterium (Elvira-Recuenco and van Vuurde 2000). In addition, ten bacterial species were identified in Jacaranda decurrens, mostly from five genera: Bacillus, Pseudomonas, Corynebacterium, Actinomyces, and Staphylococcus (Carrim et al. 2006).

Endophytes are bacteria and fungi associated with plants that do not cause any apparent disease symptoms (Clay and Schardl 2002). Many endophytes enhance the growth of their hosts (Nassar et al. 2005), improve the ability of their hosts to tolerate abiotic stresses, and enhance resistance to herbivorous insects (Czeplick and Faeth 2009). Ryan et al. (2008) categorized endophytic bacteria into four groups based on their roles: (1) microbes that promote plant growth and development through the production of phytohormones (indole-3-acetic acid) (Pietr 1990) to increase the absorption of nutrients or binding of free nitrogen, (2) microbes that produce antibiotics, immunosuppressants, and bioinsecticides, (3) microbes capable of inducing plant systemic responses, and (4) microbes that improve environmental conditions through disposal of toxic chemicals (Ryan et al. 2008). Therefore, endophytes can help plants in two ways, through the antagonistic behavior toward pathogens (production of bioactive substances) and induction of plant systemic responses.

Foliar endophytes can improve plant nutrient acquisition, protect against abiotic stress (Rodriguez et al. 2009), and mediate the interaction between plants and herbivorous insects (Hartley and Gange 2009). Studies have demonstrated that some grasses are protected against herbivorous insects through vertically transmitted endophytes, resulting in the production of toxic secondary metabolites (Schardl et al. 2004; Müller and Krauss 2005). However, the presence of endophytes can also have negative effects on the natural enemies of herbivorous insects. The composition of volatiles in plants with endophytes may be different from that of plants free of endophytes (Yue et al. 2001; Jallow et al. 2008). In addition, endophytes may also mediate herbivore-induced emission of plant volatiles, resulting in the attraction of predators of herbivorous insects (Takabayashi and Dicke 1996). For example, Pseudomonas putida produces phenazine, which protects potatoes against soft root rots caused by Erwinia carotovora, whereas pyrrolnitrin synthesized by $P$. fluorescens acts against Rhizoctonia solani (Howell and Stipanovic 1979). However, there is very little published information regarding the protective role of plant endophytes against coleopteran species. 
Some plant microbes can directly interfere with insect fitness by producing toxins. For instance Bacillus thuringiensis (Bt) produce crystal proteins acting as insecticides by forming pores in the epithelial midgut cells (Vachon et al. 2012). In addition, bacteria employ additional toxins and various effectors that interfere with insect immunity and promote infection (Nielsen-LeRoux et al. 2012). Spores of these bacteria occur in the soil. Studies have shown that these bacteria can colonize the phyllosphere, and can be taken up by the insects when they ingest plant material (Bizzarri and Bishop 2008; Mennerat et al. 2009). The toxicity of the $B t$ colonizing plant depends on bacterial strain and host plant species (Bizzarri and Bishop 2008; Monnerat et al. 2009). Bt toxin was used as a biopesticide to kill a range of leaf-eating insects (van Frankenhuyzen 2009), for instance, to limit harmfulness of $D$. virgifera virgifera in maize plantations in the USA. The field trials with $B t$ toxin started in 2003; however, in 2011, resistance of $D$. virgifera virgifera to $B t$ toxin was reported (Gassman et al. 2011). It was claimed that $B t$ needs a cooperation from commensal gut bacteria to be fully pathogenic, but Raymond et al. (2010) opposed to this hypothesis suggesting that $B t$ does not require assistance of other microbes for its pathogenicity. Therefore, additional studies should be done to clarify the mechanisms of pathogenicity of this bacterium to various insect species as well as D. virgifera virgifera resistance toward $B t$ toxin.

Information regarding the interaction among plants, insects, and bacteria is rapidly increasing as evidenced by the growing number of publications on this topic. The two-way interaction (plant-insect) had long been the subject of the research. At present, scientists start to focus rather on the three-way interaction (plant-insectmicrobes). However, in the light of emerging research showing the wealth of the bacteria inhabiting the phyllosphere as well as disclosure of further details describing the plant-insect battle as being more and more complex, it can be assumed that in the future rather the four-way insect-bacteria-bacteria-plant interactions will and should be studied. Nowadays, however, the aim is a more comprehensive understanding of the role of bacteria in the interaction between plants and insects which may lead to the development of new methods of control of harmful insects populations. This will be increasingly important as more and more insects develop insecticide resistance. This aspect is of particular interest as the phenomenon of insecticide resistance in the case of beetle pests expands rapidly (Makūnas et al. 2000). The knowledge about possible contribution of insect-associated microbes in this process would be extremely important for the development of the control strategies for the protection of the most important staple food crop around the world. In addition, another future direction in research on plant-insect interaction should be to explain the impact of insects' gut microbiota on the susceptibility of insects to pathogens (as shown previously in the case of increasing resistance toward $B$. thuringiensis toxin in $D$. virgifera virgifera). There are many original research and review articles published on the topic of microbe structural and functional diversity and the interactions between microorganisms and their plant and insect hosts (Engel and Moran 2013; Kikuchi et al. 2012; Frago et al. 2012). Our review complements what has been published so far by comprehensively reviewing the available information relevant to the biggest insect class.

Author contribution statement BW and AOS contributed to this manuscript and were involved in the drafting, preparation of models and critical revision as well as have agreed to its final content.

Acknowledgments This study was supported by the Polish National Science Grant UMO-2011/03/B/NZ9/01598.

Open Access This article is distributed under the terms of the Creative Commons Attribution 4.0 International License (http://crea tivecommons.org/licenses/by/4.0/), which permits unrestricted use, distribution, and reproduction in any medium, provided you give appropriate credit to the original author(s) and the source, provide a link to the Creative Commons license, and indicate if changes were made.

\section{References}

Adie B, Chico JM, Rubio-Somoza I, Solano R (2007) Modulation of plant defenses by ethylene. J Plant Growth Regul 26:160-177

Ahman I, Lehrman A, Ekbom B (2009) Impact of herbivory and pollination on performance and competitive ability of oilseed rape transformed for pollen beetle resistance. Arthropod Plant Interact 3:105-113

Al Abassi S, Birkett MA, Pettersson J, Pickett JA, Wadhams LJ, Woodcock CM (2000) Response of the seven-spot ladybird to an aphid alarm pheromone and an alarm pheromone inhibitor is mediated by paired olfactory cells. J Chem Ecol 26:1765-1771

Alborn HT et al (2007) Disulfooxy fatty acids from the American bird grasshopper Schistocerca americana, elicitors of plant volatiles. Proc Natl Acad Sci USA 104:12976-12981

Allsopp PG, McGhie TK (1996) Snowdrop and wheatgerm lectins and avidin as metabolites for the control of sugarcane whitegrubs. Entomol Exp Appl 80(2):409-414

Alyokhin A, Baker M, Mota-Sanchez D, Dively G, Grafius E (2008) Colorado potato beetle resistance to insecticides. Am J Potato Res 85(6):395-413

Arimura GI, Matsui K, Takabayashi J (2009) Chemical and molecular ecology of herbivore-induced plant volatiles: proximate factors and their ultimate functions. Plant Cell Physiol 50:911-923

Atamian HS et al (2013) In planta expression or delivery of potato aphid Macrosiphum euphorbiae effectors Me10 and Me23 enhances aphid fecundity. Mol Plant Microbe Interact 26(1): $67-74$

Awmack C, Leather S (2002) Host plant quality and fecundity in herbivorous insects. Annu Rev Entomol 47:817-844 
Bai XD, Correa VR, Toruno TY, Ammar ED, Kamoun S, Hogenhout SA (2009) AY-WB phytoplasma secretes a protein that targets plant cell nuclei. Mol Plant Microbe Interact 22:18-30

Ballhorn DJ, Kautz S, Lieberei R (2010) Comparing responses of generalist and specialist herbivores to various cyanogenic plant features. Entomol Exp Appl 134:245-259

Barr KL, Hearne LB, Briesacher S, Clark TL, Davis GE (2010) Microbial symbionts in insects influence down-regulation of defense genes in maize. PLoS One 5:e11339

Bartlet E, Kiddle G, Williams I, Wallsgrove R (1999) Wound-induced increases in the glucosinolate content of oilseed rape and their effect on subsequent herbivory by a crucifer specialist. Entomol Exp Appl 91:163-167

Beale MH et al (2006) Aphid alarm pheromone produced by transgenic plants affects aphid and parasitoid behavior. Proc Natl Acad Sci USA 103:10509-10513

Beattie GA (2011) Water relations in the interaction of foliar bacterial pathogens with plants. Annu Rev Phytopathol 49:533-555

Beran F, Pauchet Y, Kunert G, Reichelt M, Wielsch N, Vogel H, Reinecke A, Svatos A, Mewis I, Schmid D et al (2014) Phyllotreta striolata flea beetles use host plant defense compounds to create their own glucosinolate-myrosinase system. Proc Natl Acad Sci USA 111:7349-7354

Berendsen RL, Pieterse CMJ, Bakker PAHM (2012) The rhizosphere microbiome and plant health. Trends Plant Sci 17:478-486

Bergey DR et al (1999) A wound- and systemic-inducible polygalacturonase in tomato leaves. Proc Natl Acad Sci USA 96:1756-1760

Beutel RG, Leschen RAB (ed) (2005) Handbuch der Zoologie/ Handbook of zoology, vol 4/2. In: Insecta: Coleoptera, Beetles, vol 1. Morphology and systematic. Walter de Gruyter (ISBN-13: 978-3110171303)

Bizzarri MF, Bishop AH (2008) The ecology of Bacillus thuringiensis on the phylloplane: colonization from soil, plasmid transfer, and interaction with larvae of Pieris brassicae. Microb Ecol 56:133-139

Blight MM, Smart LE (1999) Influence of visual cues and isothiocyanate lures on capture of the pollen beetle, Meligethes aeneus in field traps. J Chem Ecol 25:1501-1516

Blomquist GJ et al (2010) Pheromone production in bark beetles. Insect Biochem Mol Biol 40(10):699-712

Bonaventure G, Van Doorn A, Baldwin IT (2011) Herbivoreassociated elicitors: FAC signaling and metabolism. Trends Plant Sci 16(6):294-299

Boone CK, Keefover-Ring K, Mapes AC et al (2013) Bacteria associated with a tree-killing insect reduce concentrations of plant defense compounds. J Chem Ecol. doi:10.1007/s10886013-0313-0

Breitenmoser S (2012) Résistance des méligèthes aux pyréthrinoïdes. Agroscope Changins-Wädenswil

Brito LO, Lopes AR, Parra JRP, Terra WR, Silva-Filho MC (2001) Adaptation of tobacco budworm Heliothis virescens to proteinase inhibitors may be mediated by the synthesis of new proteinases. Comp Biochem Physiol 128B:365-375

Broderick NA, Raffa KF, Goodman RM, Handelsman J (2004) Census of the bacterial community of the gypsy moth larval midgut by using culturing and culture-independent methods. Appl Environ Microb 70:293-300

Brown J, Scholtz CH, Janeau JL, Grellier S, Podwojewski P (2010) Dung beetles (Coleoptera: Scarabaeidae) can improve soil hydrological properties. Appl Soil Ecol 46(1):9-16

Brunelle F, Cloutier C, Michaud D (2004) Colorado potato beetles compensate for tomato cathepsin D inhibitor expressed in transgenic potato. Arch Insect Biochem Physiol 55:03-113

Burnum KE, Callister SJ, Nicora CD, Purvine SO, Hugenholtz P, Warnecke F, Scheffrahn RH, Smith RD, Lipton MS (2011) Proteasome insights into the symbiotic relationship between a captive colony of Nasutitermes corniger and its hindgut microbiome. ISME J 5(1):161-164

Burse A, Frick S, Discher S, Tolzin-Banasch K, Kirsch R, Strauß A, Kunert M, Boland W (2009) Always being well prepared for defense: the production of deterrents by juvenile Chrysomelina beetles (Chrysomelidae). Phytochemistry 70:1899-1909

Campos FAP, Xavier-Filho J, Silva CP, Ary MB (1989) Resolution and partial characterization of proteinases and a-amylases from midgets of larvae of the bruchid beetle Callosobruchus maculatus (F.). Comp Biochem Phys B 92:51-57

Cao D, Pimentel D, Hart K (2002) Postharvest crop losses (insects and mites). In: Pimentel D (ed) Encyclopedia of pest management. Marcel Dekker, New York, pp 648-649

Cardoza YJ, Klepzig KD, Raffa KF (2006) Bacteria in oral secretions of an endophytic insect inhibit antagonistic fungi. Ecol Entomol 31(6):636-645

Carlini CR et al (1997) Biological effects of canatoxin in different insect models: evidence for a proteolytic activation of the toxin by insect cathepsinlike enzymes. J Econ Entomol. doi:10.1093/ jee/90.2.340

Carrim AJI, Barbosa EC, Vieira JDG (2006) Enzymatic activity of endophytic bacterial isolates of Jacaranda decurrens Cham. (Carobinha-do-campo). Braz Arch Biol Technol 49(3):353-359

Chapman R (2003) Contact chemoreception in feeding by phytophagous insects. Annu Rev Entomol 48:455-484

Charlat S, Duplouy A, Hornett EA, Dyson EA, Davies N (2009) The joint evolutionary histories of Wolbachia and mitochondria in Hypolimnas bolina. BMC Evol Biol 9:64

Chen H, Wilkerson CG, Kuchar JA, Phinney BS, Howe GA (2005) Jasmonate-inducible plant enzymes degrade essential amino acids in the herbivore midgut. Proc Natl Acad Sci USA 102:19237-19242

Chen Z, Schlipalius D, Opti G, Subramanyam B, Phillips TW (2015) Diagnostic molecular markers for phosphine resistance in U.S. populations of Tribolium castaneum and Rhyzopertha dominica. PLOS. doi:10.1371/journal.pone.0121343

Cheplick GP, Faeth SH (2009) Ecology and evolution of the grassendophyte symbiosis. Oxford University Press, Oxford. ISBN 9780195308082

Christiansen E (2008) Eurasian spruce bark beetle, Ips typographus Linnaeus (Coleoptera: Curculionidae, Scolytinae). In: Capinera JL (ed) Encyclopedia of entomology, vol 2, pp 1363-1366. Springer, New York (ISBN 978-1-4020-6242-1)

Chu CC, Spencer JL, Curzi MJ, Zavala JA, Seufferheld MJ (2013) Gut bacteria facilitate adaptation to crop rotation in the western corn rootworm. Proc Natl Acad Sci USA 110:11917-11922

Chung SH, Felton GW (2011) Specificity of induced resistance in tomato against specialist lepidopteran and coleopteran species. J Chem Ecol 37(4):378-386

Chung SH, Rosa C, Scully ED, Peiffer M, Tooker JF, Hoover K, Luthe DS, Felton GW (2013) Herbivore exploits orally secreted bacteria to suppress plant defenses. Proc Natl Acad Sci USA 110:15728-15733

Clay K, Schardl C (2002) Evolutionary origins and ecological consequences of endophyte symbiosis with grasses. Am Nat. doi: $10.1086 / 342161$

Colgan LJ, Erbilgin N (2011) Three-mediated interactions between the jack pine budworm and a mountain pine beetle fungal associate. Ecol Entomol 36:425-434

Colman DR, Toolson EC, Takacs-Vesbach CD (2012) Do diet and taxonomy influence insect gut bacterial communities? Mol Ecol 21:5124-5137

Consales F et al (2012) Insect oral secretions suppress wound-induced responses in Arabidopsis. J Exp Bot 63(2):727-737

Cooper LD, Doss RP, Price R, Peterson K, Oliver JE (2005) Application of Bruchin $\mathrm{B}$ to pea pods results in the up-regulation 
of $C Y P 93 C 18$, a putative isoflavone synthase gene, and an increase in the level of pisatin, an isoflavone phytoalexin. J Exp Bot 56:1229-1237

Crowson RA (1981) The biology of coleopteran. Acadaemic Press, London, $\mathrm{p} 802$

Czapla TH, Lang BA (1990) Effect of plant lectins on the larval development of european corn borer (lepidopteran: Pyralidae) and southern corn borer (coleoptera: Chrysomelidae). J Econ Entomol 83:2480-2485

Daamen RA, Stol W (1993) Surveys of cereal diseases and pests in the Netherlands. 6. Occurrence of insect pests in winter wheat. Neth J Pl Path 99:51-56

Dale C, Plague GR, Wang B, Ochman H, Moran NA (2002) Type III secretion systems and the evolution of mutualistic endosymbiosis. Proc Natl Acad Sci USA 99:12397-12402

De Fine Licht HH, Schiřtt M, Rogowska-Wrzesinska A et al (2013) Laccase detoxification mediates the nutritional alliance between leaf-cutting ants and fungus-garden symbionts. Proc Natl Acad Sci USA 110:583-587

De Moraes CM, Mescher MC, Tumlinson JH (2001) Caterpillarinduced nocturnal plant volatiles repel conspecific females. Nature 410:577-580

Degenhardt J, Hiltpold I, Köllner TG, Frey M, Gierl A, Gershenzon J, Hibbard BE, Ellersieck MR, Turlings TCJ (2009) Restoring a maize root signal that attracts insect-killing nematodes to control a major pest. Proc Natl Acad Sci USA 106:13213-13218

Delphia CM, Mescher MC, Felton GQ, De Moraes CM (2006) The role of insect-derived cues in eliciting indirect plant defences in tobacco. Nicotiana tabacum. Plant Signal Behav 1(5):243-250

Després L, David JP, Gallet C (2007) The evolutionary ecology of insect resistance to plant chemicals. Trends Ecol Evol 22:298-307

Dicke M, Baldwin IT (2010) The evolutionary context for herbivoreinduced plant volatiles: beyond the 'cry for help'. Trends Plant Sci 15:167-175

Dicke M, van Poecke RMP, de Boer JG (2003) Inducible indirect defence of plants: from mechanism to ecological function. Basic Appl Ecol 4:27-42

Dickens JC (2006) Plant volatiles moderate response to aggregation to pheromone in Colorado potato beetle. J Appl Entomol 130:26-31

Dillon RJ, Dillon VM (2004) The gut bacteria of insects: nonpathogenic interaction. Annu Rev Entomol 49:71-92

Dimitrijević B, Petrić D, Ignjatović-Ćupina A, Knežević D, Mićanović D, Zečević V (2001) Influence of larvae solidity of cereal leaf beetle (Coleoptera, Chrysomelidae: Lema melanopus L.) on yield decreasing of small grains. Kragujevac J Sci 23:99-104

Discher S, Burse A, Tolzin-Banasch K, Heinemann SH, Pasteels JM, Boland W (2009) A versatile transport network for sequestering and excreting plant glycosides in leaf beetles provides an evolutionary flexible defense strategy. ChemBioChem 10:2223-2229

Doss RP, Oliver JE, Proebsting WM et al (2000) Bruchins: insectderived plant regulators that stimulate neoplasm formation. Proc Natl Acad Sci USA 97:6218-6223

Douglas AE (2009) The microbial dimension in insect nutritional ecology. Funct Ecol 23:38-47

Dowd PF, Shen SK (1990) The contribution of symbiotic yeast to toxin resistance of the cigarette beetle (Lasioderma serricorne). Entomol Exp Appl 56:241-248

Dubreuil RR, Grushko T, Baumann O (2001) Differential effects of a labial mutation on the development, structure, and function of stomach acid-secreting cells in Drosophila melanogaster larvae and adults. Cell Tissue Res 306:167-178
Eichenseer $\mathrm{H}$ et al (1999) Salivary glucose oxidase: multifunctional roles for Helicoverpa zea? Arch Insect Biochem Physiol 42:99-109

Eleftherianos L, Atri J, Accetta J, Castillo JC (2013) Endosymbiotic bacteria in insects: guardians of the immune system? Front Physiol 4:46. doi:10.3389/fphys.2013.00046

Elvira-Recuenco M, van Vuurde JWL (2000) Natural incidence of endophytic bacteria in pea cultivars under field conditions. Can J Microbiol 46(11):1036-1041

Engel P, Moran NA (2013) The gut microbiota of insects-diversity in structure and function. FEMS Microbiol Rev 37:699-735

Engel P, Martinson VG, Moran NA (2012) Functional diversity within the simple gut microbiota of the honey bee. Proc Natl Acad Sci USA 109(27):11002-11007

Engelberth J (2006) Secondary metabolites and plant defense. In: Taiz L, Zeiger E (ed) Plant Physiol, vol 4, pp 315-344. Sinauer Associates, Sunderland

Engelberth J, Alborn HT, Schmelz EA, Tumlinson JH (2004) Airborne signals prime plants against insect herbivore attack. Proc Natl Acad Sci USA 101:1781-1785

Erb M, Flors V, Karlen D, de Lange E et al (2009) Signal signature of above-ground-induced resistance upon below ground herbivory in maize. Plant J 59:292-302

Fabrick J, Behnke C, Czapla T, Bala K, Rao AG, Kramer KJ, Reeck GR (2002) Effect of potato cysteine proteinase inhibitor on midgut proteolytic enzyme activity and growth of the southern corn rootworm, Diabrotica undecimpunctata howardi (Coleoptera: Chrysomelidae). Insect Biochem Mol 32:405-415

Frago E, Dicke M, Charles H, Godfray J (2012) Insect symbionts as hidden players in insect-plant interactions. Trends Ecol Evol 127(12):705-711

Garcia-Muniz N, Martinez-Izquierdo JA, Puigdomenech P (1998) Induction of mRNA accumulation corresponding to a gene encoding a cell wall hydroxyproline-rich glycoprotein by fungal elicitors. Plant Mol Biol 38:623-627

Garcia-Olmedo F, Salcedo G, Sanchez-Monge RF, Gomez L, Royo J, Carbonero P (1987) Plant proteinaceous inhibitors of proteinases and $\alpha$-amylases. Oxf Surv Plant Mol Cell Biol 4:275-334

Gassman AJ, Petzold-Maxwell JL, Keweshan RS, Dunbar MW (2011) Field-evolved resistance to $B t$ maize by western corn rootworm. PLoS One 6(7):e22629. doi:10.1371/journal.pone. 0022629

Gatehouse AMR, Gatehouse JA (1998) Identifying proteins with insecticidal activity: use of encoding genes to produce insectresistant transgenic crops. Pestic Sci 52:165-175

Gebrehiwot L, Beuselinck PR (2001) Seasonal variations in hydrogen cyanide concentration of three Lotus species. Agron $\mathbf{J}$ 93:603-608

Geib SM (2008) Lignin degradation in wood-feeding insects. In: Kirk TK (ed) PNAS, vol 105 (35), pp 12932-12937

Ghoneim K (2013) Agronomic and biodiversity impacts of the blister beetles (Coleoptera: Meloidae) in the world: A review. Int $\mathbf{J}$ Agric Sci Res 2(2):021-036

Girard C, Le Métayer M, Bonadé-Bottino M, PhamDelègue MH, Jouanin L (1998) High level of resistance to proteinase inhibitors may be conferred by proteolytic cleavage in beetle larvae. Insect Biochem Mol Biol 28:229-237

Glazebrook J (2005) Contrasting mechanisms of defense against biotrophic and necrotrophic pathogens. Annu Rev Phytopathol 4:34506-34513

Gomes CEM, Barbosa AE, Macedo LLP, Pitanga JCM, Moura FT et al (2005) Effect of trypsin inhibitor from Crotalaria pallida seeds on Callosobruchus maculatus (cowpea weevil) and Ceratitis capitata (fruit fly). Plant Physiol Biochem PPB 43:1095-1102 
Grimaldi D, Engel MS (2005) Evolution of the insect. Cambridge University Press, Cambridge

Groll E, Wetzel T (1984) Untersuchungen zur struktur der populationen von getreidehähnchen (Oulema spp.). Lehrst Phytopathol Pflanzenschutz 97(2):113-124

Gutjahr C, Paszkowski U (2009) Weights in the balance: jasmonic acid and salicylic acid signaling in root-biotroph interactions. Mol Plant Microbe Interact 22:763-772

Hammerbacher A, Schmidt A, Wadke N et al (2013) A common fungal associate of the spruce bark beetle metabolizes the stilbene defenses of Norway spruce. Plant Physiol 162: $1324-1336$

Hanley ME, Lamont BB, Fairbanks MM, Rafferty CM (2007) Plant structural traits and their role in antiherbivore defense perspect. Plant Ecol Evol Syst 8:157-178

Hartley SE, Gange AC (2009) Impacts of plant symbiotic fungi on insect herbivores: mutualism in a multitrophic context. Annu Rev Entomol 54:323-342

Hause B, Schaarschmidt S (2009) The role of jasmonates in mutualistic symbioses between plants and soil-born microorganisms. Phytochemistry 70:1589-1599

Heimbach U, Muler A, Thieme T (2007) First steps to analyse pyrethroid resistance of different oilseed rape pests in Germany. Nachr Deutsch Pflanz 58:1-5

Hernández CA, Pujol M, Alfonso-Rubí J et al (2003) Proteolytic gut activities in the rice water weevil, Lissorhoptrus brevirostris Suffrian (Coleoptera: Curculionidae). Arch Insect Biochem 53(1):19-29

Hilker M, Meiners T (2010) How do plants "notice" attack by herbivorous arthropods. Biol Rev Camb Physol 85(2):267-280

Hosseininaveh V, Bandani A, Azmayeshafard Hosseinkhani S, Kazzazi M (2007) Digestive proteolytic and amylolytic activities in Trogoderma granarium Everts (Dermestidae: Coleoptera). J Stored Prod Res 43:515-522

Houseman JG, Thie NMR (1993) Difference in digestive proteolysis in the stored maize beetles: Sitophilus zeamais (Coleoptera: Curculionidae) and Prostephanus truncatus (Coleoptera: Bostrichidae). J Econ Entomol 86:1049-1054

Howe GA, Jander G (2008) Plant immunity to insect herbivore: a dynamic interaction. N Phytol 156:145-169

Howell CR, Stipanovic RD (1979) Control of Rhizoctonia solani on cotton seedlings with Pseudomonas fluorescens and with an antibiotic produced by the bacterium. Phytopathology 69:480-482

Hoy CW, Head GP, Hall FR (1998) Spatial heterogeneity and insect adaptation to toxins. Annu Rev Entomol 43:571-594

Hughes DP, Brodeur J, Thomas F (2012) Host manipulation by parasites. Oxford University Press, Oxford

Hunt T, Bergsten J, Levkanicova Z, Papadopoulou A et al (2007) A comprehensive phylogeny of beetles reveals the evolutionary origins of a super-radiation. Science 318:1913-1916

Ishimoto M, Sato T, Chrispeels MJ, Kitamura K (1996) Bruchid resistance of transgenic azuki bean expressing $\alpha$-amylase inhibitor of common beans. Entomol Exp Appl 79:309-315

Jallow MFA, Dugassa-Gobena D, Vidal S (2008) Influence of an endophytic fungus on host plant selection by a polyphagous moth via volatile spectrum changes. Arthropod Plant Interact 2:53-62

Jander G, Cui JP, Nhan B, Pierce NE, Ausubel FM (2001) The TASTY locus on chromosome 1 of Arabidopsis affects feeding of the insect herbivore Trichoplusia ni. Plant Physiol 126:890-898

Jeyaprakash A, Hoy MA (2000) Long PCR improves Wolbachia DNA amplification: $w s p$ sequences found in $76 \%$ of sixty-three arthropod species. Insect Mol Biol 9:393-405

Jood S, Kapoor AC, Singh R (1993) Available carbohydrates of cereal grains as affected by storage and insect infestation. Plant Food Hum Nutr 43:45-54
Kaiser W, Huguet E, Casas J, Commin C, Giron D (2010) Plant green-island phenotype induced by leaf-miners is mediated by bacterial symbionts. Proc Biol Sci 277:2311-2319

Kaloshian I, Walling LL (2005) Hemipterans as plant pathogens. Annu Rev Phytopathol 43:491-521

Karban R, Baldwin IT, Baxter KJ, Laue G, Felton GW (2000) Communication between plants: induced resistance in wild tobacco plants following clipping of neighboring sagebrush. Oecologia 125:66-71

Kazachkova NI (2007) Genotype analysis and studies of pyrethroid resistance of the Oilseed rape (Brassica napus) Insect pest Pollen beetle (Meligethes aeneus). Thesis of Swedish University of Agricultural Sciences, pp 1-20

Keeling CI, Yuen MM, Liao NY, Docking TR, Chan SK, Taylor GA, Palmquist DL, Jackman SD, Nguyen A, Li M et al (2013) Draft genome of the mountain pine beetle, Dendroctonus ponderosae Hopkins, a major forest pest. Genome Biol 14:R27

Kerin J (1994) Opening address. In: Proceedings of the 6th international working conference on stored-product protection, vol 1, pp xix-xx, 17-23 April 1994, Canberra

Kessler A, Baldwin IT (2001) Defensive function of herbivoreinduced plant volatile emissions in nature. Science 291:2141-2144

Kessler A, Halitschke R, Baldwin IT (2004) Silencing the jasmonate cascade: induced plant defenses and insect populations. Science 305:665-668

Kikuchi Y et al (2012) Symbiont-mediated insecticides resistance. Proc Natl Acad Sci USA. doi:10.1073/pnas.1200231109

Kitch LW, Murdock LL (1986) Partial characterization of a major gut thiol proteinase from larvae of Callosobruchus maculatus (F.). Arch Insect Biochem 3:561-575

Koga R, Tsuchida T, Fukatsu T (2003) Changing partners in an obligate symbiosis: a facultative endosymbiont can compensate for loss of the essential endosymbiont Buchnera in an aphid. Proc R Soc B Biol Sci 270:2543-2550

Kohl KD, Dearing MD (2012) Experience matters: prior exposure to plant toxins enhances diversity of gut microbes in herbivores. Ecol Lett 15:1008-1015

Koiwa H, Bressan RA, Hasegawa PM (1997) Regulation of protease inhibitors and plant defense. Trends Plant Sci 2(10):379-384

Kölsch G, Matz-Grund C, Pedersen BV (2009) Ultrastructural and molecular characterization of endosymbionts of the reed beetle genus Macroplea (Chryomelidae, Donaciinae), and proposal of "Candidatus Macropleicola appendiculatae" and "Candidatus Macropleicola muticae". Can J Microbiol 55:1250-1260

Koornneefer A, Leon-Reyes A, Ritsema T, Verhage A, Den Otter FC, Van Loon LC et al (2008) Kinetics of salicylate-mediated suppression of jasmonate signaling reveal a role for redox modulation. Plant Physiol 147:1358-1368

Korada RR, Naskar SK, Prasad AR, Prasuna AL, Jyothi KN (2010) Differential volatile emission from sweet potato plant: mechanism of resistance in sweet potato or weevil Cylas formicarius (Fab.). Curr Sci 99:1597-1601

Kramer KJ, Muthukrishnan S (1997) Insect chitinases: molecular biology and potential use as biopesticides. Insect Biochem Mol Biol 27:887-900

Krattiger AF (1997) Insect resistance in crops: a case study of Bacillus thuringiensis $(B t)$ and its transfer to developing countries. ISAAA Briefs $2: 42$

Krawczyk K, Szymańczyk M, Obrępalska-Stęplowska A (2015) Prevalence of endosymbionts in polish populations of Leptinotarsa decemlineata (Coleoptera: Chrysomelidae). J Insect Sci 15(1):106

Kromp B (1999) Carabid beetles in sustainable agriculture: a review on pest control efficacy, cultivation aspects and enhancement. Agr Ecosyst Environ 74(1-3):187-228 
Kuhn J, Pettersson EM, Feld BK, Burse A, Termonia A, Pasteels JM, Boland W (2004) Selective transport systems mediate sequestration of plant glucosides in leaf beetles: a molecular basis for adaptation and evolution. Proc Natl Acad Sci USA 101:13808-13813

Lawrence SD, Novak NG (2006) Expression of poplar chitinase in tomato leads to inhibition of development in colorado potato beetle. Biotechnol Lett 28:593-599

Lawrence SD, Novak NG, Blackburn MB (2007) Inhibition of proteinase inhibitor transcripts by Leptinotarsa decemlineata regurgitant in Solanum lycopersicum. J Chem Ecol 33(5):1041-1048

Lawrence SD, Novak NG, Ju CJ, Cooke JE (2008) Potato, Solanum tuberosum, defense against Colorado potato beetle, Leptinotarsa decemlineata (Say): microarray gene expression profiling of potato by Colorado potato beetle regurgitant treatment of wounded leaves. J Chem Ecol 34(8):1013-1025

Lemos FJA, Xavier-Filno J, Campos FAP (1987) Proteinases of the midgut of Savrotes subfasciatus larvae. Agric Biol Tecnoi 80:46

Leplé JC et al (1995) Toxicity to Chrysomela tremulae (Coleoptera: Chrysomelidae) of transgenic poplars expressing a cysteine proteinase inhibitor. Mol Breed 1(4):319-328

Levine E, Oloumi-Sadeghi H (1996) Western corn rootworm (Coleoptera: Chrysomelidae) larval injury to corn grown for seed production following soybeans grown for seed production. J Econ Entomol 89:1010-1016

Li X, Schuler MA, Berenbaum MR (2007) Molecular mechanisms of metabolic resistance to synthetic and natural xenobiotics. Annu Rev Entomol 52:231-253

Login FH, Heddi A (2012) Insect immune system maintains longterm resident bacteria through a local response. J Insect Physiol 59:232-239

Loughrin JH, Potter DA, Hamilton-Kemp TR (1995) Volatile compounds induced by herbivory act as aggregation kairomones for the Japanese beetle (Popillia japonica Newman). J Chem Ecol 21:1457-1467

Loughrin JH, Potter DA, Hamilton-Kemp TR, Byers ME (1996) Role of feeding-induced plant volatiles in aggregative behavior of the Japanese beetle (Coleoptera: Scarabaeidae). Environ Entomol 25:1188-1191

Lowe S, Browne M, Boudjelas S, DePoorter M (2000) 100 of the world's worst invasive alien species: a selection from the global invasive species database. http://www.issg.org/booklet.pdfS. Invasive Species Specialist Group, World Conservation Union (IUCN)

Lugtenberg B, Kamilova F (2009) Plant-growth-promoting rhizobacteria. Annu Rev Microbiol 63:541-555

MakūnasV, Brazauskienė I, Šmata R (2000) Resistance of Meligethes aeneus to pyrethroids in Lithuania. In: Žemdirbyste agriculture, vol 98 (4) (ISSN 1392-3196:431-438)

Mason CJ, Raffa KF (2014) Acquisition and structuring of midgut bacterial communities in gypsy moth (Lepidoptera: Erebidae) larvae. Environ Entomol 43:595-604

Mason CJ, Rubert-Nason KF, Lindroth RL, Raffa KE (2015) Aspen defense chemicals influence midgut bacterial community composition of gypsy moth. J Chem Ecol 41:75-84

Mattiacci L et al (1995) $\beta$-Glucosidase: an elicitor of herbivoreinduced plant odor that attracts host-searching parasitic wasps. Proc Natl Acad Sci USA 92:2036-2040

McInroy JA, Kloepper JW (1995) Survey of indigenous bacterial endophytes from cotton and sweet corn. Plant Soil 173:337-342

Mennerat RG, Soares CM, Capdeville G, Jones G, Martins ES, Praca L, Cordeiro BA, Braz SV, dos Santos RC, Berry C (2009) Translocation and insecticidal activity of Bacillus thuringiensis living inside of plants. Microb Biotechnol 2:512-520
Michaud D, Nguyen-Quoc B, Yelle S (1993) Selective inhibition of Colorado potato beetle cathepsin $\mathrm{H}$ by oryzacystatin I and II. FEBS Lett 331:173-176

Minoretti N, Weisser WW (2000) The impact of individual ladybirds (Coccinella septempunctata, Coleoptera, Coccinellidae) on aphid colonie. Eur J Entomol 97:475-479 (ISSN 1210-5759)

Morton RL, Schroeder HE, Bateman KS, Chrispeels MJ, Armstrong E, Higgins TJV (2000) Bean $\alpha$-amylase inhibitor 1 in transgenic peas (Pisum sativum) provides complete protection from pea weevil (Bruchus pisorum) under field conditions. Proc Natl Acad Sci USA 97:3820-3825

Müller CB, Krauss J (2005) Symbiosis between grasses and asexual fungal endophytes. Curr Opin Plant Biol 8:450-456

Murdock LL, Brookhart G, Dunn PE, Foard DE, Kelley S (1987) Cysteine digestive proteinases in Coleoptera. Comput Biochem Phys B 87:783-787

Nassar AH, El-Tarabily KA, Sivasithamparam K (2005) Promotion of plant growth by an auxin-producing isolate of the yeast Williopsis saturnus endophytic in maize (Zea mays L.) roots. Biol Fertil Soils 42(2):97-108

Nielsen-LeRoux C, Gaudriault S, Ramarao N, Lereclus D, Givaudan A (2012) How the insect pathogen bacteria Bacillus thuringiensis and Xenorhabdus/Photorhabdus occupy hosts. Curr Opin Microbiol 15:220-231

Nishida R (2002) Sequestration of defensive substances from plants by Lepidoptera. Annu Rev Entomol 47:57-92

Noge K, Abe M, Tamogami S (2011) Phenylacetonitrile from the giant knotweed, Fallopia sachalinensis, infested by the Japanese Beetle, Popillia japonica, is induced by exogenous methyl jasmonate. Molecules 16:6481-6488

Ogendo JO, Omolo EO, Deng AL, Matasyoh JC, Tabu IM (2006) Field grain losses and insect pest management practices in subsistence agriculture: farmers' perceptions. J Agric Sci Technol 8(1):24-42

Oliveira AS, Migliolo L, Aquino RO, Ribeiro JKC, Macedo LLP, Andrade LBS, Bemquerer MP, Santos EA, Kiyota S, Sales MP (2007) Purification and characterization of a trypsin-papain inhibitor from Pithecelobium dumosum seeds and its in vitro effects towards digestive enzymes from insect pests. Plant Physiol Biochem 45:858-865

Oliver KM, Degnan PH, Burke GR, Moran NA (2010) Facultative symbionts in aphids and the horizontal transfer of ecologically important traits. Annu Rev Entomol 55:247-266

Oppert B, Morgan TD, Kramer KJ (2004) Inhibitor strategies to control coleopteran pests, vol 1275, pp 149-156. In Morris S, Vosloo A (eds) International congress series, animals and environments. Proceedings of the third international conference of comparative physiology and biochemistry. Elsevier, Amsterdam

Oppert B, Morgan TD, Hartzer K, Kramer KJ (2005) Compensatory proteolytic responses to dietary proteinase inhibitors in the red flour beetle, Tribolium castaneum (Herbst) (Coleoptera: Tenebrionidae). Comput Biochem Physiol 140:53-58

Optiz SEW, Muller C (2009) Plant chemistry and insect sequestration. Chemoecology 19:117-154

Orr GL, Strickland JA, Walsh TA (1994) Inhibition of Diabrotica larval growth by a multicystatin from potato tubers. J Insect Physiol 40:893-900

Osborn TC, Alexander DC, Sun SSM, Cardona C, Bliss FA (1988) Insecticidal activity and lectin homology of arcelin seed protein. Science 240:207-210

Pankoke H, Bowers MD, Dobler S (2012) The interplay between toxin releasing $\beta$-glucosidase and plant iridoid glycosides impairs larval development in a generalist caterpillar, Grammia incorrupta (Arctiidae). Insect Biochem Mol 42(6):426-434

Pare PW, Tumlinson JH (1999) Plant volatiles as a defense against insect herbivores. Plant Physiol 121:325-332 
Pathak MD, Khan ZR (1994) Insect pests of rice. International Rice Research Institute (ISBN 971-22-0028-0)

Pauchet Y, Kirsch R, Giraud S, Vogel H, Heckel D (2014) Identification and characterization of plant cell wall degrading enzymes from three glycoside hydrolase families in the carambydic beetle Apriona japonica. Insect Biochem Mol 49:1-13

Paulillo LCMS, Lopes AR, Cristofoletti PT, Parra JRP, Terra WR, Silva-Filho MC (2000) Changes in midgut endopeptidase activity of Spodoptera frugiperda (Lepidoptera: Noctuidae) are responsible for adaptation to soybean proteinase inhibitors. J Econ Entomol 93:892-896

Pedezzi R, Fonseca FPP, Santos CD Jr, Kishi LT, Terra WR, Henrique-Silva $F$ (2014) A novel $\beta$-fructofuranosidase in Coleoptera: characterization of a $\beta$-fructofuranosidase from the sugarcane weevil. Sphenophorous levis. Insect Biochem Mol Biol 1(55C):31-38

Pernas M, Lopez-Solanilla E, Sanchez-Monge R, Salcedo G, Rodriguez-Palenzuela P (1999) Mol Plant Microbe Interact 12:624-627

Phillips TW, Throne JE (2010) Biorational approaches to managing stored-product insects. Annu Rev Entomol 55:375-397

Pickett JA, Wadhams LJ, Woodcock CM, Hardie J (1992) The chemical ecology of aphids. Annu Rev Entomol 37:67-90

Pieterse CMJ, Van der Does D, Zamioudis C, Leon-Reyes A, Van Wees SCM (2012) Hormonal modulation of plant immunity. Annu Rev Cell Dev Bi 28:489-521

Pietr S (1990) Wpływ saprofitycznej mikroflory ryzosfery na wzrost roślin. Post Nauk Rol 3:19-38

Pike KC, Gould M (2002) Yield loss and insecticide study with CLB in irrigated spring wheat (Unpublished data)

Raffa KF, Aukema BH, Erbilgin N, Klepzig KD, Wallin KF (2005) Interactions among conifer terpenoids and bark beetles across multiple levels of scale: an attempt to understand links between population patterns and physiological processes. In: Romeo JT (ed) Recent advances in phytochemistry. Elsevier, New York, pp 79-118

Rajendran S (2002) Postharvest pest losses. In: Pimental D (ed) Encyclopedia of pest management. Marcel Dekker, New York, pp 654-656

Rao MB, Tanksale M, Ghatge MS, Deshpande VV (1998) Molecular and biotechnological aspects of microbial proteases. Microbiol Mol Biol R 62(3):597-635

Rasmann S, Köllner TG, Degenhardt J, Hiltpold I, Toepfer S, Kuhlmann U, Gershenzon J, Turlings TCJ (2005) Recruitment of entomopathogenic nematodes by insect-damaged maizeroots. Nature 434:732-737

Raymond B, Johnston PR, Nielsen-LeRoux C, Lereclus D, Crickmore N (2010) Bacillus thuringiensis: an impotent pathogen? Trends Microbiol 18(5):189-194

Robert-Seilaniantz A, Grant M, Jones JD (2011) Hormone crosstalk in plant disease and defense: more than just jasmonate-salicylate antagonism. Annu Rev Phytopathol 49:317-343

Rodriguez RJ, White JF, Arnold AE, Redman RS (2009) Fungal endophytes: diversity and functional roles. New Phytol 182:314-330

Ryan CA (2000) The systemin signaling pathway: differential activation of plant defensive genes. Biochem Biophys Acta 1477:112-121

Ryan RP, Germaine K, Franks A, Ryan DJ, Dowling DN (2008) Bacterial endophytes: recent developments and applications. FEMS Microbiol Lett 278:1-9

Schardl CL, Leuchtmann A, Spiering MJ (2004) Symbioses of grasses with seedborne fungal endophytes. Annu Rev Plant Biol 55:315-340

Schmelz EA, Grebenok RJ, Galbraith DW, Bowers WS (1999) Insect induced synthesis of phytoecdysteroids in spinach, Spinacia oleracea. J Chem Ecol 25:1739-1757
Schmelz EA et al (2006) Fragments of ATP synthase mediate plant perception of insect attack. Proc Natl Acad Sci USA 103:8894-8899

Schoonhoven LM, Jeremy T, Van Loon JJA (1998) Insect-plant biology. From physiology to evolution. Chapman \& Hall, London

Schowalter TD (2011) Resource acquisition. In: Schowalter T (ed) Insect ecology. Academic Press, San Diego, pp 53-93

Senderovich Y, Halpern M (2013) The protective role of endogenous bacterial communities in chironomid egg masses and larvae. ISME J 11:2147-2158

Shao Q, Yang B, Xu Q, Li X, Lu Z, Wang C, Huang Y, Söderhäll K, Ling E (2012) Hindgut innate immunity and regulation of fecal microbiota through melanization in insects. J Biol Chem 287(17):14270-14279

Sharma K (2015) Protease inhibitors in crop protection from insects. Int J Curr Res Aca Rev 3(2):55-70

Shulke RH, Murdock LL (1983) Lipoxygenase trypsin inhibitor and lectin from soybeans: effects on larval growth of Manduca sexta (Lepidoptera: Sphingidae). Env Ento 12:787-791

Spoel SH, Koornneef A, Claessens SMC, Korzelius JP, Van Pelt JA, Mueller MJ et al (2003) NPR1 modulates cross-talk between salicylate- and jasmonate-dependent defense pathways through a novel function in the cytosol. Plant Cell 15:760-770

Stam JM, Kroes A, Li Y, Gols R, van Loon JJA, Poelman EH, Dicke M (2014) Plant interaction with multiple insect herbivores: from community to genes. Annu Rev Plant Biol 65:689-713

Starr DJ, Cline TW (2002) A host parasite interaction rescues Drosophila oogenesis defects. Nature 418:76-79

Strang TJK, Kigawa R (2006) Levels of IPM control: matching conditions to performance and effort. Collect Forum 21:96-116

Sturz AV, Christie BR, Matheson BG, Arsenault WJ, Buchanan NA (1999) Endophytic bacterial communities in the periderm of potato tubers and their potential to improve resistance to soilborne plant pathogens. Plant Pathol 48:360-369

Takabayashi J, Dicke M (1996) Plant-carnivore mutualism through herbivore-induced carnivore attractants. Trends Plant Sci 1:109-113

Tang X, Freitak D, Vogel H, Ping L, Shao Y, Cordero EA et al (2012) Complexity and variability of gut commensal microbiota in polyphagous lepidopteran larvae. PLoS One 7:e36978

Terra WR, Cristofoletti PT (1996) Midgut proteinases in three divergent species of Coleoptera. Comput Biochem Physiol B 113:725-730

Terra WR, Ferreira C (1994) Insect digestive enzymes: properties, compartmentalization and function. Comput Biochem Physiol 109B:1-62

Thaler JS, Humphrey PT, Whiteman NK (2012) Evolution of jasmonate and salicylate signal crosstalk. Trends Plant Sci 17(5):260-270

Thie NMR, Houseman JG (1990) Cysteine and serine proteolytic activities in larval midgut of yellow mealworm, Tenebrio molitor L. (Coleoptera: Tenebrionidae). Insect Biochem 20:741-744

Ton J, Flors V, Mauch-Mani B (2009) The multifaceted role of ABA in disease resistance. Trends Plant Sci 14:310-317

Torres-Vera R, Garcia JM, Pozo MJ, López-Ráez JA (2014) Do strigolactones contribute to plant defence? Mol Plant Pathol 15:211-216

Tratwal A, Bandyk A, Jakubowska M, Roik K, Wielkopolan B (2014) Stan fitosanitarny roślin uprawnych w Polsce w roku 2014 i spodziewane wystąpienie agrofagów w 2015. Instytut Ochrony Roślin Państwowy Instytut Badawczy w Poznaniu (ISSN 1898-7419)

Tumlinson JH, Paré PW, Lewis WJ (1999) Plant production of volatile semiochemicals in response to insect-derived elicitors. In: Chadwick DJ, Goode JA (ed) Insect-plant interactions and induced plant defence. Wiley, Chichester, pp 95-109 
Turlings TCJ, Loughrin JH, McCall PJ, Röse US, Lewis WJ, Tumlinson JH (1995) How caterpillar-damaged plants protect themselves by attracting parasitic wasps. Proc Natl Acad Sci USA 92:4169-4174

Vachon V, Laprade R, Schwartz JL (2012) Current models of the mode of action of Bacillus thuringiensis insecticidal crystal proteins: a critical review. J Invertebr Pathol 111:1-12

Vallet-Gely I, Lemaitre B, Boccard F (2009) Bacterial strategies to overcome insect defences. Nat Rev Microbiol 6:302-313

Van Dam NM, Horn M, Mares M, Baldwin IT (2001) Ontogeny constrains systemic protease inhibitor response in Nicotiana attenuata. J Chem Ecol 27:547-568

van Frankenhuyzen K (2009) Insecticidal activity of Bacillus thuringiensis crystal proteins. J Invertebr Pathol 101:1-16

Van Loon LC (1999) The families of pathogenesis-related proteins, their activities, and comparative analysis of PR-1 type proteins. Physiol Mol Plant Pathol 55:85-97

van Tol RWHM, van der Sommen ATC, Boff MIC, van Bezooijen J, Sabelis MW, Smits PH (2001) Plants protect their roots by alerting the enemies of grubs. Ecol Lett 4:292-294

Verhage A (2011) Rewiring of the jasmonic acid signaling pathway during insect herbivory on Arabidopsis. PhD thesis, Utrecht University, Utrecht

Visôtto LE, Oliveira MGA, Guedes RNC, Ribon AOB, Good-God PIV (2009) Contribution of the gut bacteria to digestion and development of the velvetbean caterpillar. Anticarsia gemmatalis. J Insect Physiol 55:185-191

Voelckel C, Baldwin IT (2004) Generalist and specialist lepidopteran larvae elicit different transcriptional responses in Nicotiana attenuate, which correlate with larval FAC profiles. Ecol Lett 7:770-775

Von Dahl C, Baldwin IT (2007) Deciphering the role of ethylene in plant-herbivore interactions. J Plant Growth Regul 26:201-209

von Mérey G, Veyrat N, Mahuku G, Valdez RL, Turlings TCJ, D'Alessandro M (2011) Dispensing synthetic green leaf volatiles in maize fields increases the release of sesquiterpenes by the plants, but has little effect on the attraction of pest and beneficial insects. Phytochemistry 72:1838-1847

Wade MJ, Chang NW (1995) Increased male fertility in Tribolium confusum beetles after infection with the intracellular parasite Wolbachia. Nature 373:72-74

Wade MJ, Stevens L (1985) Microorganisms mediated reproductive isolation in flour beetles (Genus Tribolium). Science 227:527-528

Walling LL (2009) Adaptive defense responses to pathogens and insects. In: Loon LCV (ed) Advances in botanical research: plant innate immunity. Academic Press, London, pp 551-612

War AR, Paulraj MG, Ahmad T, Buhroo AA, Hussain B, Ignacimuthu S, Sharma HC (2012) Mechanisms of plant defense against insect herbivores. Plant Signal Behav 7(10):1306-1320

Watanabe T, Fujita H, Sakai S (2001) Effects of jasmonic acid and ethylene on the expression of three genes for wound-inducible 1-aminocyclopropane-1-carboxylate synthase in winter squash (Cucurbita maxima). Plant Sci 161:67-75

Wesseler J, Fall EH (2010) Potential damage costs of Diabrotica virgifera virgifera infestation in Europe-the 'no control' scenario. J App Entomol 134:385-394

White JA, Kelly SE, Perlman SJ, Hunter MS (2009) Cytoplasmic incompatibility in the parasitic wasp Encarsia inaron: disentangling the roles of Cardinium and Wolbachia symbionts. Heredity 102:483-489

Wielkopolan B, Walczak F, Podleśny A, Nawrot R, ObrępalskaStęplowska A (2015) Identification and partial characterization of proteases in larval preparations of the cereal leaf beetle (Oulema melanopus, Chrysomelidae, Coleoptera). Arch Insect Biochem Physiol 88(3):192-202

Wieman NF, Nielsen SS (1988) Isolation and partial characterization of a major gut proteinase from larval Acanthoscelides obtectus Say (Coleoptera: bruchidae). Comput Biochem Phys B 89:419-426

Wilhite SE, Elden TC, Joze Brzin J, Smigocki AC (2000) Inhibition of cysteine and aspartyl proteinases in the alfalfa weevil midgut with biochemical and plant-derived proteinase inhibitors. Insect Biochem Mol 30:1181-1188

Wolfson JL, Murdock LL (1987) Suppression of larval Colorado potato beetle growth and development by digestive proteinase inhibitors. Entomol Exp Appl 44:235-240

Wright R, Meinke L, Jarvi K (1999) Corn rootworm management. University of Nebraska. Retrieved 03 February 2007

Yue Q, Wang C, Gianfagna TJ, Meyer WA (2001) Volatile compounds of endophyte-free and infected tall fescue (Festuca arundinacea Schreb.). Phytochemistry 58:935-941

Zamojska J, Mrówczyński M, Węgorek P (2011) Current status of resistance level in pollen beetle (Meligethes aeneus F.) and cabbage seed weevil (Ceutorhynchus assimilis Payk) to selected active substances of insecticides. In: Poland 13th International Rapeseed Congress, Czech Republic

Zhao Y, Botella MA, Subramanian L, Niu X, Nielsen SS, Bresan RA, Hasegawa PM (1996) Two wound-inducible soybean cysteine proteinase inhibitors have great insect digestive proteinase inhibitory activites than a constitutive homolog. Plant Physiol 111(4):1299-1306

Zhu F, Poelman EH, Dicke M (2014) Insect herbivore-associated organisms affect plant response to herbivory. New Phytol 204:315-321

Zhu-Salzman K, Koiwa H, Salzman RA, Shade RE, Ahn JE (2003) Cowpea bruchid Callosobruchus maculatus uses a three-component strategy to overcome a plant defensive cysteine protease inhibitor. Insect Mol Biol 12:135-145

Zug R, Hammerstein P (2012) Still a host of hosts for Wolbachia: analysis of recent data suggests that $40 \%$ of terrestrial arthropod species are infected. PLoS One 7:e38544 